\title{
Fifteen years of dancing with vanadium*
}

\author{
Debbie C. Crans
}

Department of Chemistry, Colorado State University, Fort Collins, CO 80523, USA

\begin{abstract}
The advances in vanadium chemistry over the past 15 years are discussed in the areas of solution chemistry, coordination chemistry, and bioinorganic chemistry and will be presented using the perspectives of "What exists in solution?", "What is its structure?", "How does it react?", and "What are its biological effects?". Current and future challenges will be described briefly.
\end{abstract}

Keywords: Vanadium; solution chemistry; structure; reactivity; biological effects; speciation; $\mathrm{X}$-ray structure; spectroscopy; kinetics; insulin-enhancing.

\section{INTRODUCTION}

Vanadium is an early first-row transition metal and forms colorful compounds in its many different oxidation states. It undergoes a wide variety of chemistry depending on the electronic and steric nature of the coordinating ligands. In higher oxidation states, vanadium is very oxophilic, but at low oxidation states, $\pi$-donating ligands such as dinitrogen and carbon monoxide are preferred. It is the only element in the periodic table that is named after a goddess (the Nordic goddess Vanadis), and perhaps with this legacy brings to the table a sense of some unpredictable and surprising chemistry. Two decades ago, vanadium chemistry, particularly vanadium $(\mathrm{V})$ chemistry, was significantly less developed than it is now. Many aspects of vanadium $(\mathrm{V})$ chemistry in solution that are now well known were about to be discovered. A compendium of contributions dedicated to vanadium chemistry edited by Chasteen [1], showed the number of publications in the area of vanadium chemistry increased dramatically from the early to the late 1980s. This level of interest has continued unabated, thus leading to the much more mature field that exists presently.

In this paper, I describe some key developments that have taken place in the past 15 years, and in this manner celebrate state-of-the-art solution chemistry, advances in vanadium chemistry, and vanadium science as a result of this progress. The catalytic and material properties of vanadium compounds and their effects in biological systems have long provided the impetus and fuel to studies of vanadium science [1-17]. Thus far, my group and I have focused on fundamental chemical studies of the various systems in which certain biological responses are observed or anticipated. The barriers between bioinorganic and other areas of vanadium science are now less obvious; systems of interest to bioinorganic chemists have catalytic properties, and systems known for their catalytic properties have relevance to bioinorganic chemistry [17]. Important aspects of our approach involved a series of fundamental questions: "What species exist in solution?", "What are the structures of the species in solution?", "How do the species react?", and "What are their biological effects?". Our approaches to these questions first involved a combination of structural chemistry with spectroscopic studies to char-

*Paper based on the first Vanadis Award lecture presented at the $4^{\text {th }}$ International Symposium on Chemistry and Biological
Chemistry of Vanadium, Szeged, Hungary, 3-5 September 2004. Other presentations are published in this issue, pp. 1497-1640. 
acterize the solution speciation. With such information in place, we went to the next step and examined how each species reacted and the possible effects they could induce in a biological system.

\section{STUDIES PAVING THE WAY FOR EXPLORATION OF AQUEOUS VANADIUM(V) CHEMISTRY}

The spectroscopic characterization of the oxovanadates by Howarth and coworkers $[18,19]$ and that of alkylated oxovanadates, i.e., vanadate esters, as reported by the Gresser and Tracey team [20-22] were key studies in the area of vanadium(V) solution chemistry. The first study showed that both ethylvanadate and vanadate diethyl ester form when vanadate is in the presence of high levels of ethanol at pH 7.5 (Fig. 1) [20]. In addition, these studies underlined the applicability of ${ }^{51} \mathrm{~V}$ NMR spectroscopy and for the next decade we and other groups began to explore aqueous chemistry using this technique. The Rehder group had been a proponent for applications of ${ }^{51} \mathrm{~V}$ NMR spectroscopy for some time, and had shown that vanadium has a very large chemical shift window, that readily allows for the identification of different compounds [23-25]. The vanadium nucleus is very sensitive to small structural variations, and is a very effective tool for investigation of vanadium compounds in solution. The radio frequency for observation of vanadium is in a convenient range, and in fact, now ${ }^{51} \mathrm{~V}$ NMR spectroscopy is a method of choice for many scientists working with vanadium(V) compounds.

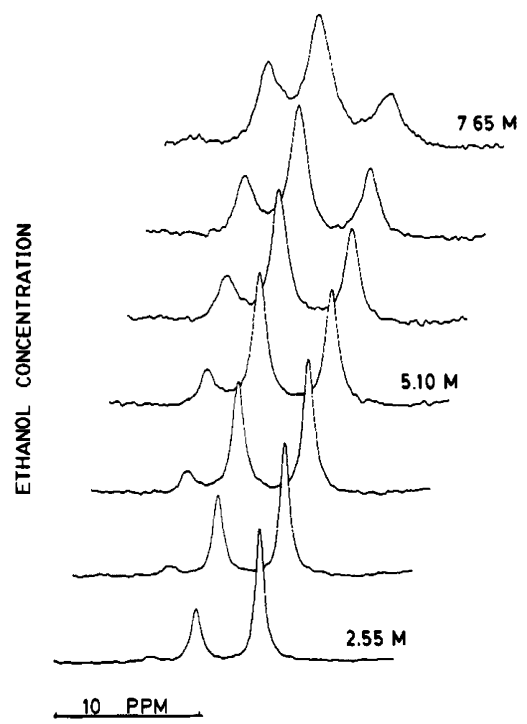

Fig. ${ }^{51} \mathrm{~V}$ NMR of $0.39 \mathrm{mM}$ vanadate in the presence of increasing concentrations of ethanol at pH 7.5 in $50 \mathrm{mM}$ tris-acetate buffer. The signal for monomeric vanadate (at highest field), ethylvanadate (center signal), and diethyl vanadate (at lowest field). Reprinted with permission from ref. [20]. Copyright (C1985 American Chemical Society.

Two decades ago, the nature of the oxovanadates forming in aqueous solution were not well characterized $[18,19]$, and each species reactivity was relatively unexplored under any conditions of interest to life scientists. Spectroscopic studies using ${ }^{51} \mathrm{~V}$ NMR showed that the colorless solutions of oxovanadates above millimolar concentrations at neutral and alkaline $\mathrm{pH}$ contain monomer $\left(\mathrm{V}_{1}\right)$, dimer $\left(\mathrm{V}_{2}\right)$, tetramer $\left(\mathrm{V}_{4}\right)$, and pentamer $\left(\mathrm{V}_{5}\right)$ formed from pure vanadate salts [18]. At that time, the speciation was less understood and the signal now assigned to $\mathrm{V}_{4}$, was believed by some to be a trimer because in some concentration ranges the distinction is not readily made [26-28]. A combination of spectroscopy and titration did, however, show that the species forming the signal contained four V-atoms $[29,30]$. Although studies investigating the speciation and simple oxovanadate systems were 
reported in the early 1980s, high 3.0 M perchlorate ionic strength solutions were typically used to assure a constant ionic medium for investigations. These high salt concentrations affect the speciation and consequently modified the chemistry of the system, making them less relevant to physiological conditions. Studies at lower ionic strength began to emerge and demonstrated quantitative differences, but no qualitative differences in the speciation [29,31-33]. Combined potentiometric and NMR studies were particularly powerful in detailing the properties of oxovanadates $[29,30]$, which were critical for the studies that explored the reactions of vanadium $(\mathrm{V})$ in the physiological relevant $\mathrm{pH}$ range. Such studies were carried out by the Tracey/Gresser group [20-22], the Crans group [34-36], the Rehder group [23,37,38], and others [39-41].

The question of how fast the oxovanadates and other systems in aqueous solutions reacted remained open, although most considered the reaction fast because the systems under investigation had equilibrated by the time of analysis. The possibility that some vanadium(V) complexes might be slowly interconverting was generally not considered, even though it was recognized that decavanadate interconverted slowly above neutral $\mathrm{pH}$. Early on, we tackled the question of the kinetics of oxovanadate interconversions [36]. In solutions containing the simple oxovanadate mixture $\left(\mathrm{V}_{1}, \mathrm{~V}_{2}, \mathrm{~V}_{4}\right.$, and $\left.\mathrm{V}_{5}\right)$ all the oxovanadates interconvert on a millisecond time scale as shown in the EXSY $2 \mathrm{D}^{51} \mathrm{~V}$ NMR spectrum of a solution of vanadate at $\mathrm{pH} 8.6$, Fig. 2. At neutral $\mathrm{pH}$ and at intermediate ionic strength, $\mathrm{V}_{2}$ is the most reactive species, which presumably relates to this species' structure. This oxometalate does not enjoy the stabilization of a cyclic structure as do $\mathrm{V}_{4}\left(\left[\mathrm{~V}_{4} \mathrm{O}_{12}\right]^{-}\right)$and $\mathrm{V}_{5}\left(\left[\mathrm{~V}_{5} \mathrm{O}_{15}\right]^{-}\right)$. Indeed, EXSY 2D NMR spectroscopy is ideal for studies of these aqueous systems where many of the species are in equilibrium, because the conversion of several species can be followed simultaneously. This method and also ${ }^{1} \mathrm{H}$ and ${ }^{13} \mathrm{C}$ EXSY spectroscopy have been used successfully to investigate the reactions of a range of vanadium(V) systems [42-47].

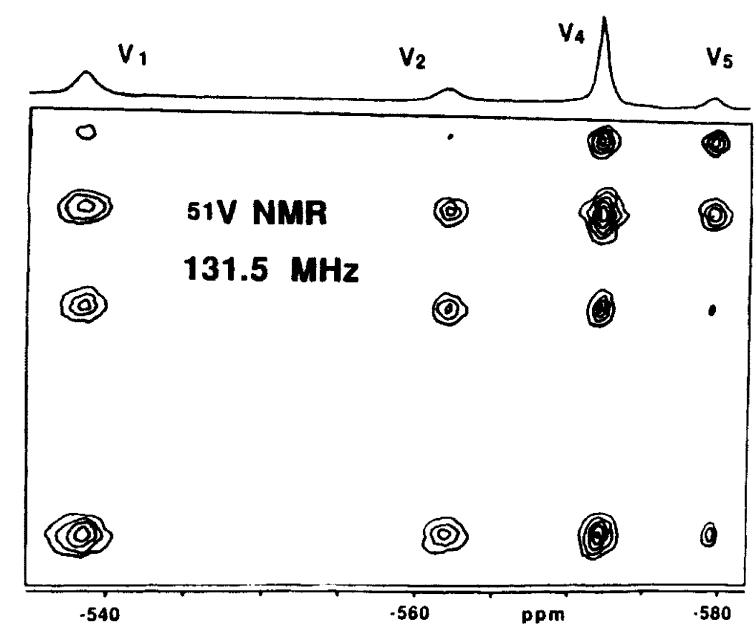

Fig. $2^{51} \mathrm{~V}$ 2D EXSY NMR spectroscopy of a $10 \mathrm{mM}$ sodium vanadate solution at pH 8.6. The off-diagonal signals reflect exchange between oligomers, whereas the diagonal signals represent the 1D spectrum. The assignments of the signals are given on the vertical axis. Reprinted with permission from ref. [36]. Copyright (C) 1990 American Chemical Society.

\section{REACTION OF VANADATE WITH ORGANIC LIGANDS IN AQUEOUS SOLUTION}

The reaction of vanadate with ethanol [20] was the first of a series of organic systems that included numerous coordinating functionalities such as hydroxyl [20,21], carboxyl [35,48,49], amino [35,38,50,51], amido [52-54], phospho [22,55], and bi- [21,35,38,49,56] and multidentate [34,37,39,51,53-55,57-62] combinations of these moieties. The Tracey/Gresser team in the early stud- 
ies mapped out what types of complexes formed, the $\mathrm{pH}$ dependence of complex formation, and the stoichiometry of the systems. This approach was followed in most subsequent studies. In general, vanadate esters and vanadate carboxylates form weak complexes unless the functionalities are part of bidentate or multidentate ligand framework $[20,21,35,48,49]$. The complexes formed with amino and amido groups are even weaker [35,38,50-54]. In contrast, complexes with phosphate groups are more stable $[22,55]$. These early studies provided an important framework on which subsequent studies of these complexes were based. For example, the complex formed between diethanolamine and vanadate shows a Gaussian (bell-curve) stability profile, and correlate with the concentration of $\mathrm{V}_{1}$ and the ratio of $\left[\mathrm{VO}_{2} \mathrm{dea}\right]^{-} /\left[\mathrm{V}_{1}\right]$, Fig. 3. Thus, both the $\mathrm{p} K_{\mathrm{a}}$ of the ligand and the $\mathrm{p} K_{\mathrm{a}}$ of $\mathrm{V}_{1}\left(\mathrm{H}_{2} \mathrm{VO}_{4}{ }^{-} / \mathrm{HVO}_{4}{ }^{2-}\right)$ contribute to give the optimal $\mathrm{pH}$ for complex stability [34].

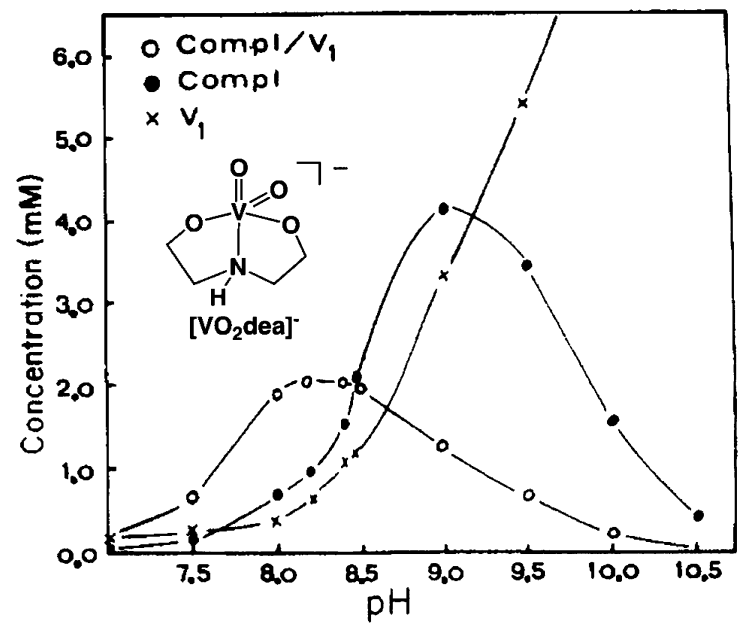

Fig. 3 Concentration of $\left[\mathrm{VO}_{2} \mathrm{dea}\right]^{-}(-)$, concentration of monomeric vanadate, $\mathrm{V}_{1}(\mathrm{x})$ and the ratio of $\left.\left[\mathrm{VO}_{2} \mathrm{dea}\right]^{-/} / \mathrm{V}_{1}\right](\bigcirc)$ plotted as a function of $\mathrm{pH}$. Reprinted with permission from ref. [34]. Copyright (C)1988 American Chemical Society.

The formation of ternary complexes has been a target of increasing interest over the past decade. Precedence for the existence of ternary complexes with both monodentate [43] and bidentate [40] ligands was established in early ${ }^{51} \mathrm{~V}$ NMR spectroscopic studies in aqueous solutions. Although complexes formed with monodentate ligands were not as stable as those formed with bidentate ligands, the spectroscopic data clearly showed that they do form.

The Crans group characterized some of these early systems by aggressively exploring the questions "What exists in solution?" and "What is its structure?". In our first study, in which mainly ${ }^{51} \mathrm{~V}$ NMR spectroscopy was used, we described the complexes that form between vanadate and the commonly used "good buffers" as well as a wide range of structurally related ligands [34]. This study alerted others to the problems associated with studies involving buffered vanadate solutions. In addition, this study demonstrated the effects of subtle structural changes in ligand on complex formation*.

\footnotetext{
*The Gaussian stability curves for these complexes, and for similar dipicolinate complexes, suggest that the chemistry that is taking place above and below the $\mathrm{p} K_{\mathrm{a}}$ value of vanadate involves different properties of the ligands. Tracey has proposed that when the primary ligand has a $K_{\mathrm{a}}$ below that of vanadate, then bidentate chelation with a heteroligand will be favored, whereas monodentate chelation with the same heteroligand will be favored when the primary ligand has a $\mathrm{p} K_{\mathrm{a}}$ higher than vanadate. At present, these considerations primarily seem to apply to five-coordinate complexes. Information on seven-coordinate complexes with hydroxylamido and peroxo ligands follows a similar trend. However, insufficient information is available to test this proposal on coordinatively saturated systems such as octahedral complexes. (Tracey, in preparation).
} 
The systematic modification of ligand structure and its consequent effect on complex stability demonstrated the preferred tridentate coordination of the diethanolamine ligand [34]. Some structural aspects of the ligand can be modified without preventing complex formation. For instance, substitution of one hydroxyl group with a carboxylate unit yields products, whereas the substitution of the center amino group with an ether group prevented formation of a stable complex.

More recently, the Crans group investigated the effects of sterics and solvation in these complexes by characterizing the thermodynamic parameters of the reaction [63]. The enthalpic contribution was the major term determining the stability of the complex, and opposed by the entropic term. Alkylation of the coordinating $\mathrm{N}$-moiety was found to affect the stability of the vanadium(V) complex depending on the size of the alkyl group. With small alkyl groups, no difference in complex stability was observed and showed that the small electronic effect was countered by a small entropic effect. On the other hand, if the alkyl group was an ethyl group the entropic term increased significantly and since it was only partially countered by the enthalpic term, the overall result is a less stable complex. Addition of large bulky alkyl groups can affect solvation depending on the geometry of the ligand [63]. This point was demonstrated by enantiospecific substitution of two phenol groups on the diethanolamine ligand giving a chiral diethanolamine-substituted ligand and a corresponding meso form [64]. The vanadium(V) complex prepared from chiral ligand $\left(C_{2}-2,2^{\prime}\right.$-diphenyliminodiethanol) possessed a much greater entropic term resulting in an overall much less stable vanadium $(\mathrm{V})$ complex than the complex formed from meso-2,2'-diphenyliminoethanol. Very few thermodynamic studies of vanadium(V) systems, including the simple vanadate system, have been reported [31,32]; no other study exists which examines a series of structurally related complexes. The ethanolamine and even tris(hydroxylmethyl)ethane units in these ligands are very common, and have become a common synthetic target, perhaps in part because of their structural relationship to amino acids.

The interactions of vanadate and aqueous vanadium(IV) with buffers, amino acids, peptides, and proteins were investigated at micromolar concentrations [35]. This study was carried out at low concentration in order to investigate the chemistry of both vanadate and vanadyl cation in the absence of oligomers and the affinity of both vanadate and aqueous vanadium(IV) for amino acids, dipeptides, and selected proteins; a measurable affinity was demonstrated even at these low concentrations of vanadium [35].

Recent efforts in the Crans group have been on the characterization of the vanadium-dipicolinate systems. The spectroscopic studies of the vanadium $(\mathrm{V})$ system have been combined with potentiometric studies by the Kiss group and have included studies across oxidation states [47,65-68]. Thus, the detailed speciation of the vanadium(IV) and (V) systems have been reported and an important comparison of the vanadium(IV) and vanadium(V) system was done [66]. The speciation of the vanadium(V) system reflects the high stability of the $\left[\mathrm{VO}_{2} \text { dipic }\right]^{-}$at acidic $\mathrm{pH}$ (Fig. 4). Upon reduction, the $\mathrm{V}(\mathrm{IV})$-dipic system $\left(\left[\mathrm{VO}(\mathrm{dipic})\left(\mathrm{H}_{2} \mathrm{O}\right)_{2}\right]\right.$ or $\left[\mathrm{VO}(\mathrm{dipic})_{2}\right]^{2-}$ ) exhibits higher stability near neutral $\mathrm{pH}$. Importantly, the vanadium(IV) system has both $1: 1$ and 1:2 complexes forming, with the $1: 1$ complex being more stable at higher $\mathrm{pH}$ values. If the actions of vanadium compounds in biological systems are to be understood, it is critical that we characterize systems across oxidation states in a quantitative manner. Indeed, the Crans group, in collaboration with the Buglyo group, has recently carried out studies of the corresponding vanadium(III)-dipicolinate system, and a detailed comparison across three oxidation states is also available for the dipicolinato system [69]. Indeed, these studies suggest that vanadium(III) systems can be much more stable than is commonly recognized. 

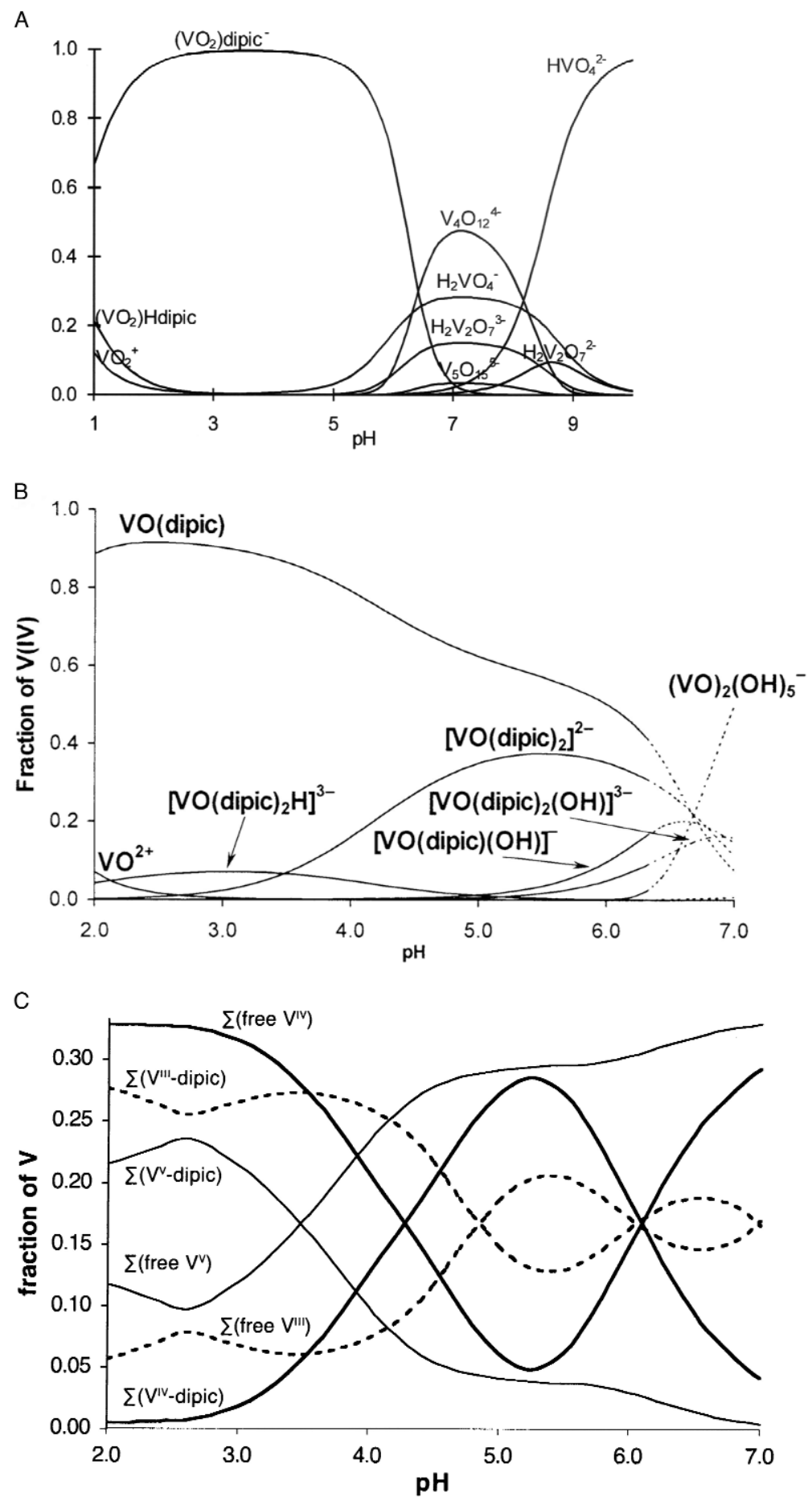

Fig. 4 Speciation of $\mathrm{V}(\mathrm{V})$ and $\mathrm{V}(\mathrm{IV})$-dipicolinate systems. (A) V(V)-dipic with $2.00 \mathrm{mM} \mathrm{V(V)} \mathrm{and} 2.00 \mathrm{mM}$ dipicligand. (B) VO(IV)-dipic with $2.00 \mathrm{mM} \mathrm{V(IV)} \mathrm{and} 4.00 \mathrm{mM}$ dipic-ligand. (C) A gedanken experiment in which formation constants for the $\mathrm{V}(\mathrm{III}), \mathrm{V}(\mathrm{IV})$, and $\mathrm{V}(\mathrm{V})$-dipicolinate complexes were all combined to compare complex stability across oxidation states, $\mathrm{V}_{\text {tot }}=2.0$ and $3.00 \mathrm{mM}$ dipic-ligand. Reprinted with permission from refs. $[65,66]$. Copyright $\odot 2000$ American Chemical Society and 2002 Elsevier. 


\section{WHAT ARE THE STRUCTURES OF VANADIUM COMPLEXES IN SOLUTION?}

Characterizing the molecular structure is a critical component of understanding the properties of a complex and the determination of X-ray structure remains an important endeavor in all areas of chemistry. This section will describe results using the tools of solid state and modeling compounds to probe the coordination chemistry of vanadium $(\mathrm{V})$ complexes and in particular demonstrate the validity of the vanadium $(\mathrm{V})$-phosphorus analogy. This is important, because in complexes where the metal ion is prone to ligand exchange, dissolution of pure solid compound often results in a complex that has a coordination geometry different from that of the solid. Although most inorganic chemists know this fact, applications of these complexes in catalysis or in biology are commonly employed without considering this fundamental inherent uncertainty in the analysis. This is partly because it is often difficult and not experimentally trivial to determine if the complex undergoes a chemical change upon dissolution. Furthermore, effects are more readily rationalized when a particular molecular structure is assumed. When new classes of compounds are prepared, their introduction often contain some structural information as part of their characterization [17]. Indeed, many new vanadium complexes are entered into the Cambridge Crystallographic Data Centre on a yearly basis with 191 entries in 2000, 181 entries in 2001, 218 entries in 2002, 99 in 2003, and 100 through November 2004. Many of these systems have been reviewed elsewhere, and are too numerous to be described here [1,3-5,10,11,13,14,16,17]. At this time, studies in several groups target the question "What is the structure?" of the vanadium complexes that form and exist in both aqueous and organic solution, and the background information for this level of understanding will be reviewed.

The Crans group was the first group probing the solution structure of systems by generating the solid-state data upon which a framework could be built $[17,60,72]$. The ${ }^{51} \mathrm{~V}$ NMR studies are necessary to document the stoichiometry and the number of different types of species that exist in solution. However, detailed structural analysis requires multiple approaches including X-ray crystallography of solid-state materials as well as additional spectroscopic studies in solution probing connectivity and ligand coordination. An early and particularly pleasing example of these types of studies is the investigation of the vanadate-triethanolamine and vanadate-tripropanolamine systems $[34,44,60]$. The initial ${ }^{51} \mathrm{~V}$ NMR studies on this system $[34,44]$ was followed by the synthesis of the complex in both organic and aqueous solvent, X-ray crystallographic characterization of the solid material in addition to multinuclear NMR studies in aqueous solution [60]. By ${ }^{13} \mathrm{C}$ and ${ }^{1} \mathrm{H}$ NMR spectroscopy and coordination-induced shifts (CISs), it was established that the species in aqueous solution had one ethanolamine/propanolamine arm free and two coordinated to the vanadium atom. This structure (1) was different from the structure in organic solvents and in the solid state ([VO(tpa)]) [60]. The two possible structures in aqueous solution are one with the cis-dioxo group in the same plane as the tripropanolamine nitrogen atom, $\mathbf{2}$, and one with the two oxo groups trans to the tripropanolamine nitrogen and oxygen atoms, 3 , respectively. Should the former structure exist in solution, ${ }^{17} \mathrm{O}$ NMR studies would result in only one signal, whereas the second structure would result in two ${ }^{17} \mathrm{O}$ NMR signals for this structure. The solution spectrum, Fig. 5, shows two signals of equal intensity in the ${ }^{17} \mathrm{O}$ NMR spectrum. This demonstrated that the compound formed in solution has the structure depicted in 3 [60].

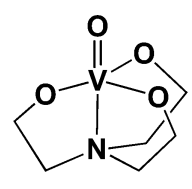

1

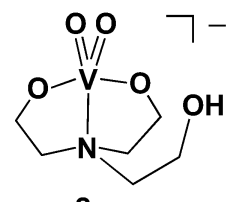

2

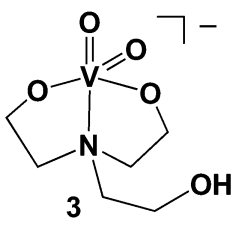




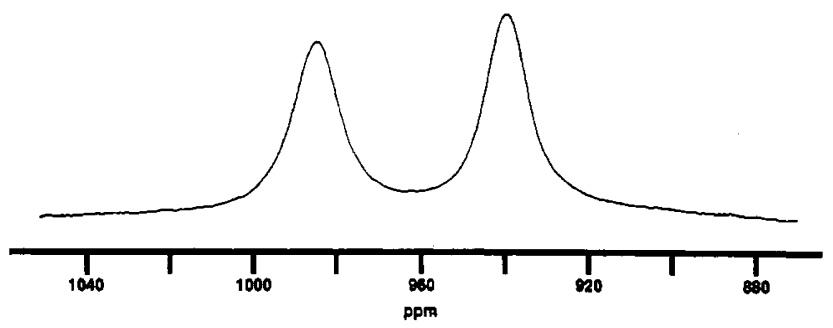

Fig. 5 The ${ }^{17} \mathrm{O}$ NMR spectrum recorded from solutions of $200 \mathrm{mM}$ vanadate, $600 \mathrm{mM}$ tripropanolamine (tpa)-ligand in the presence of $15 \%{ }^{17} \mathrm{O} \mathrm{H}_{2} \mathrm{O}$. The two signals of equal intensity rule out the possibility that $\mathbf{2}$ is the structure of the complex in solution, although the possibility of a six-coordinate structure has not been eliminated. Adapted with permission of the American Chemical Society [60].

For vanadium $(\mathrm{V})$ alkoxides, (also referred to as vanadate esters in the literature) where an alkoxide is an O-ligated alcohol, the situation is more complex. These compounds are very reactive and several species form in solution and furthermore, many scientists do not view vanadium(V) alkoxides as vanadate esters and vice versa. Regardless of their classification, proper structural precedent did not exist for either vanadium alkoxides or vanadate esters before the 1990s. As a result, demonstration of the structural analogy between vanadium(V) and phosphorus was a goal that several groups focused on for the next decade. This focus was justified by the potential use of vanadium compounds for probes in biological systems, and the fact that the only vanadium(V) alkoxide structure known was an early, poorly refined X-ray crystal structure which contained six-coordinate vanadium [70]. Thus, from a structural perspective, the four- or five-coordinate vanadate ester suggested by the vanadium(V)-phosphorus analogy in the 1980s although assumed and widely accepted was not actually based on structural precedent of model compounds or other compounds isolated from either organic or aqueous solution.

The Crans group and the Rehder group have investigated a wide range of vanadium(V) alkoxide systems over the past 15 years. The first structurally characterized model systems showed the tendency of vanadium(V) to form five-coordinate alkoxides [71-76]. A vanadium(V) alkoxide formed from the reaction of pinacol with $\mathrm{VOCl}_{3}$ provided this structural precedent for the transition-state structure used in biological studies (4) [72], modeling the vanadate-ribonuclease complex [77,78]. This five-coordinate dimer provided an example of what is now recognized to be the characteristic diamond core found in other alkoxide complexes [72]. The vanadium(V) chloroethanol alkoxide (5) from the Rehder group was the first example of such a complex with monodentate alkoxide substituents [71]. Other groups contributed, and a complex with a hydroxycarboxylic acid by Hambley and Lay was reported [79]. Some systems were found to support vanadium(V) alkoxides in six-coordinate environments were described [80]. A particularly interesting complex formed from cyclopentanol and the diamond core here contains dramatically uneven $\mathrm{V}-\mathrm{O}$ bond lengths documenting some structural flexibility, Fig. 6 [73].

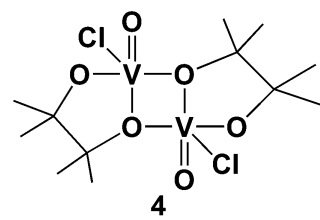<smiles></smiles><smiles></smiles> 


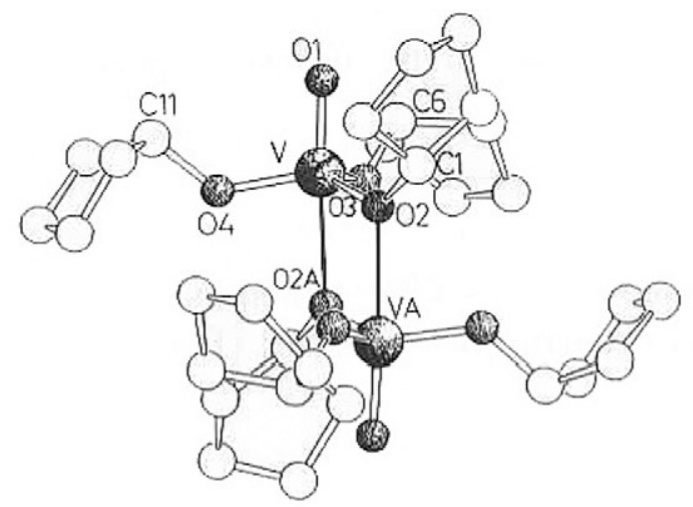

Fig. 6 The X-ray structure for the tris(cyclopentanol)oxovanadium(V) showing the uneven character of the V-O bonds in the diamond core. Reprinted with permission from ref. [75]. Copyright @1992 Elsevier.

A few early studies also provided precedent for four-coordinate vanadium(V) in model systems. To a model chemist, a chloro group is a reasonable substitute for a hydroxy group in nonaqueous solutions. Indeed this replacement used by the Zubieta group provided the first structural example of a monomeric vanadium(V) alkoxide complex with four-coordinate vanadium [81]. A dinuclear complex from ethylenediol demonstrated that four-coordinate vanadium $(\mathrm{V})$ was a very stable alternative to the five-coordinate form [76,82]. The vanadium(V) alkoxides associate in solution [83], but the high reactivity could be decreased if bulky ligands were employed, and a variety of such systems have been reported (see below for more details) [75,84]. A recent and important example of a four-coordinate vana$\operatorname{dium}(\mathrm{V})$ alkoxide has been reported with three 2,6-diisopropylphenoxide substituents (6) [85]. This structure demonstrates that the vanadium $(\mathrm{V})$ can indeed be four-coordinate, but that the sterics and the electronics of this must be very finely tuned.

Many different classes of vanadium $(\mathrm{V})$ alkoxides now exist, and the reader is referred to the Cambridge Crystallographic Data Centre [1,3-5,10-14,16,17,86-90]. The Rosenthal group [91,92] has recently reported an interesting example of this type of chemistry. The mixed vanadium(V) chloroalkoxides investigated are of interest for their application as catalysts, and their coordination chemistry is showing a wide range of geometries with four-, five-, and six-coordinate vanadium(V) in mono and dinuclear complexes with bridged chloro groups [91,92]. As more structures with bridging chlorides such as shown in $\mathbf{7}$, and their reactivity become available, a better understanding of the structural preferences in these systems will be forthcoming.

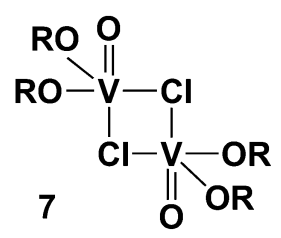

Although many model compounds have been isolated from nonaqueous media, some model systems are coordination compounds that can be isolated from aqueous media. The most studied system is that of vanadium $(\mathrm{V})$ complexes with nucleoside ligands, which were found to be potent inhibitors for ribonucleases $[77,78]$. This area will only briefly be summarized here since it has recently been reviewed in greater detail, describing the work by several groups probing the aqueous solution structure of these potent inhibitors [17]. The studies required several problems to be overcome including a small stability constant for the 1:1 complex, a large stability constant for the 2:2 complex, and overlapping signals of the major 2:2 complex and the active 1:1 inhibiting complex [93]. Many model studies were 
carried out, and some correctly predicted the coordination geometry around the vanadium atom in aqueous solution $[72,94]$. The Tracey group recently reported an X-ray structure of a vanadium complex with adenosine, Fig. 7 [71,72]; this structure shows a five-coordinate vanadium atom coordinated to the nucleoside in the diamond core motif found in the earliest model system [95].

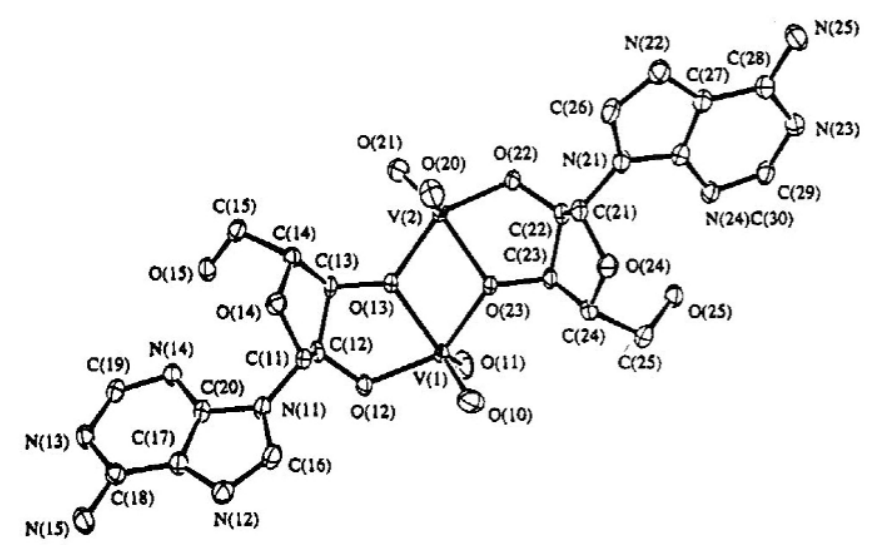

Fig. 7 The X-ray structure of the vanadium(V)-adenosine complex. Highlights in this structure include the fivecoordinate vanadium atom and the diamond core connecting the 2:2 complex. Reprinted with permission from ref. [95]. Copyright (C) 1995 American Chemical Society.

The structures of the various oxovanadates [mononuclear $\left(\mathrm{V}_{1}\right)$, dinuclear $\left(\mathrm{V}_{2}\right)$, tetranuclear $\left(\mathrm{V}_{4}\right)$, pentanuclear $\left(\mathrm{V}_{5}\right)$, and decanuclear $\left(\mathrm{V}_{10}\right)$ systems] in solution are of fundamental interest. In addition, their structures may affect which complexes can form from solutions containing oxovanadates. Information on these anions is within the area of polyoxometalates and the areas of materials science interested in vanadium oxides. Information is available on the structures of the simple oxovanadates existing in solution $[18,26,96]$; more than $100 \mathrm{X}$-ray structures have now been reported for different cation-anion combinations involving some form of the $\mathrm{V}_{10} \mathrm{O}_{28}{ }^{6-}$ anion. Information in this area impacting reactions of oxovanadates with ligands has been summarized recently [17], but more structural information is available directly from the Cambridge Crystallographic Data Centre. Studies probing vanadium alkoxide systems often result in the characterization of small- to medium-sized clusters capped by alkoxide ligands. Examples of some such systems will be summarized below from the point of view of reactivity of the vanadium compounds in solution.

\section{HOW DO VANADIUM COMPLEXES REACT IN ORGANIC SOLVENTS?}

How compounds react remains a central chemical question because the answer to this question dictates the applications of the compounds and thus their overall importance. Reactivity will always be very sensitive to whether the system is in an organic or aqueous environment, and if such differences are investigated, this is helpful for understanding the solution reactivity of these compounds. The difference between the chemistry of vanadium $(\mathrm{V})$ alkoxides in organic solvents and the corresponding studies for the vanadate esters in aqueous solutions will be described here.

Vanadium(V) alkoxides associate to form dimers (eq. 1) and oligomers at millimolar and higher concentrations in organic solvents and in liquid form. The reaction is easily monitored by ${ }^{51} \mathrm{~V}$ NMR chemical shifts, which change upon association [83]. Association has even taken place to form charged derivatives in alcoholic solutions containing base (eq. 2), Fig. 8 [97]. Association with alcohols has also been observed for other classes of compounds in which the vanadium is less than six-coordinate (eq. 3) [60], and an equilibrium between five- and six-coordinate species is established. At submillimolar concentrations, the vanadium(V) alkoxides are monomeric, and any studies carried out at low concentra- 
tions will describe the monomeric species exclusively. Bulky ligands have been shown to reduce association of the vanadium $(\mathrm{V})$ alkoxides in organic solvents. No change in the chemical shifts for compounds such as tri(t-butoxide)oxovanadium $(\mathrm{V})$, tri(adamantyloxide)oxovanadium $(\mathrm{V})$, and tri(norbonyloxide)oxovanadium(V) are observed in the ${ }^{51} \mathrm{~V}$ NMR spectra. This implies that no association takes place in solution even at $10 \mathrm{mM}$ and higher concentrations of vanadium(V) alkoxide [75,84]. Steric bulk can also slow down hydrolysis reactions [84], and it becomes possible to observe vanadium(V) alkoxides in which one or two of the alkoxide groups have been replaced with an $\mathrm{OH}$ group. For example, a species attributed to the hydrolysis product for the tri(adamantoxide)oxovanadium(V), presumably di(adamantoxide)(hydroxo)oxovanadium(V), was observed by ${ }^{51}$ V NMR spectroscopy in ethanol [84].

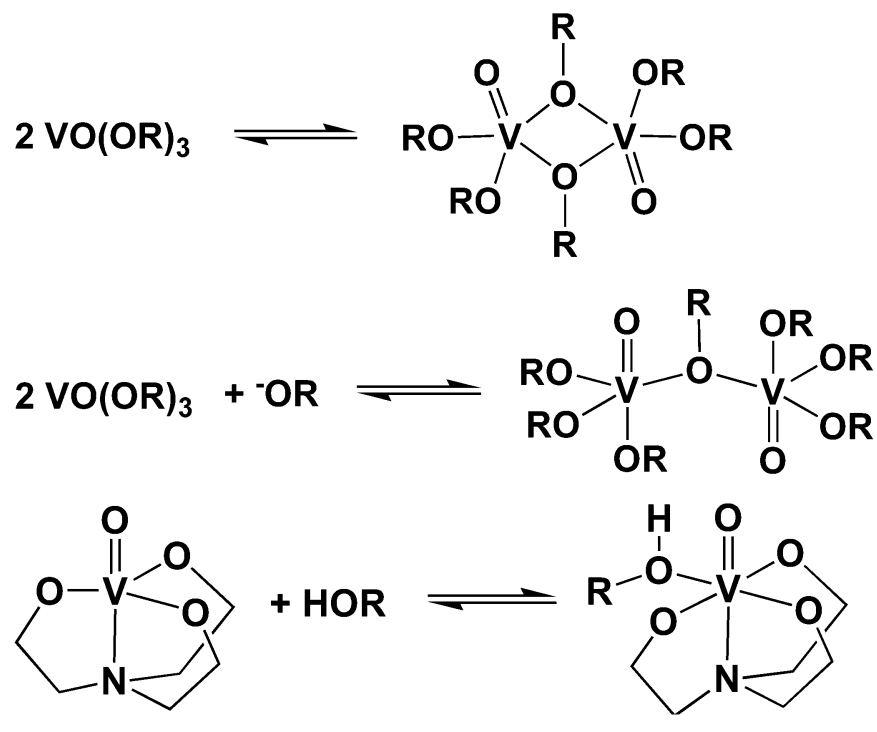

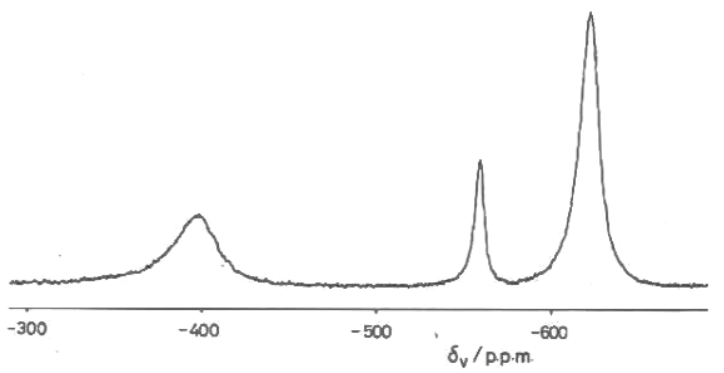

Fig. $8{ }^{51} \mathrm{~V}$ NMR spectrum of a solution containing $\left[\mathrm{VO}(\mathrm{O}-i \mathrm{Pr})_{3}\right]$ and $\mathrm{NaO}-i \mathrm{Pr}$ in $\mathrm{HO}-i \mathrm{Pr}$. Reprinted with permission from ref. [97]. Copyright @ 1987 Elsevier.

The reactions of vanadium(V)-alkoxide systems are very sensitive to subtle changes in ligand geometry and their electronic properties. The chloro-substituted vanadium(V) alkoxides are an interesting group of compounds that have been successfully investigated. The vanadium(V) chloro-alkoxides that form from 1,2-diols associate and generally form dimeric complexes, both in the solid state and in solution $[72,79,82]$. Calculations probing these geometries revealed that the coordination preference could not be attributed to the electrostatic properties of the vanadium, but rather to the subtle ligand effect often referred to as the gem-dimethyl effect [76]. Upon substitution of a second alkoxide group with a chloro group, a monomeric four-coordinate vanadium(V) dichloro-alkoxide complex forms [91] suggesting that the addition of the second chloro group shifted the favored geometry. 
Substituting the 1,2-diol with a 1,3-diol increases the distance between the ligand oxygen atoms and affects the ligand arrangements around the vanadium atom. In such cases, clusters are often isolated where the ligand is either flexible as in the saturated diol case [74], or rigid as in the 1,3-acac arrangement [98]. If the chloro group is replaced by an alkoxo group in the vanadium(V)-chloro-alkoxides, the materials containing 1,2-diols can be insoluble, presumably reflecting their polymeric nature [80].

Vanadium(IV) acetylacetonate ([VO(acac) $\left.\left.{ }_{2}\right]\right)$ is a commonly used precursor for the synthesis of many vanadium complexes. In polar solvents, $\left[\mathrm{VO}(\mathrm{acac})_{2}\right]$ will associate with the solvent [99-101], and studies by EPR spectroscopy have recently shown that both a cis and a trans isomer form when the polar solvent is water, Fig. 9 [102]. The major complex has the solvent molecule entering trans to the oxo group, whereas in the minor complex the solvent molecule enters cis to the oxo group. A minor distortion of the vanadium out of the plane toward the oxo group is sufficient to make the geometric arrangement with the incoming solvent molecule trans to the oxo group very attractive. Substituting the acac ligand with a pyridone ligand (e.g., maltol) in a vanadium(IV) alkoxide complex also resulted in the formation of two complexes in solution Fig. 10. However, the stability pattern reverses, and the favored complex for $[\mathrm{VO} \text { (malto) }]_{2}$ is the $\operatorname{cis}$ - $[\mathrm{VO} \text { (malto) }]_{2}$ adduct [103]. The application of $\left[\mathrm{VO}(\mathrm{acac})_{2}\right]$ as an oxidizing agent in organic synthesis is presumably linked to its ability to associate with organic substrates, which is then followed by electron transfer $[6,7]$.

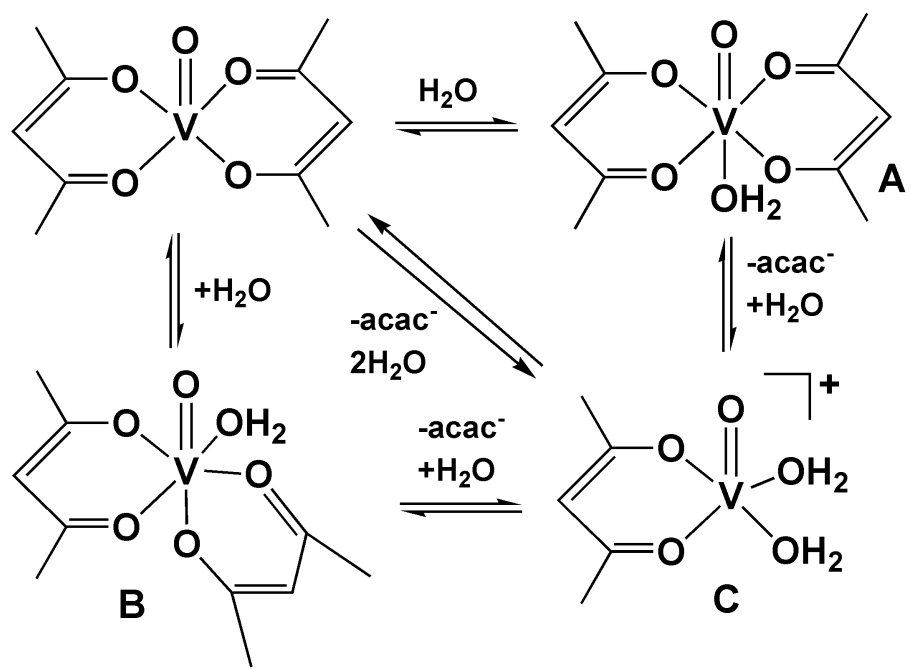

Fig. 9 Reactions of $\left[\mathrm{VO}(\mathrm{acac})_{2}\right]$ with $\mathrm{H}_{2} \mathrm{O}$ to form the trans adduct (A), the cis adduct (B) and the 1:1 hydrolysis product. Reprinted with permission from ref. [102]. Copyright (C) 2000 American Chemical Society. 


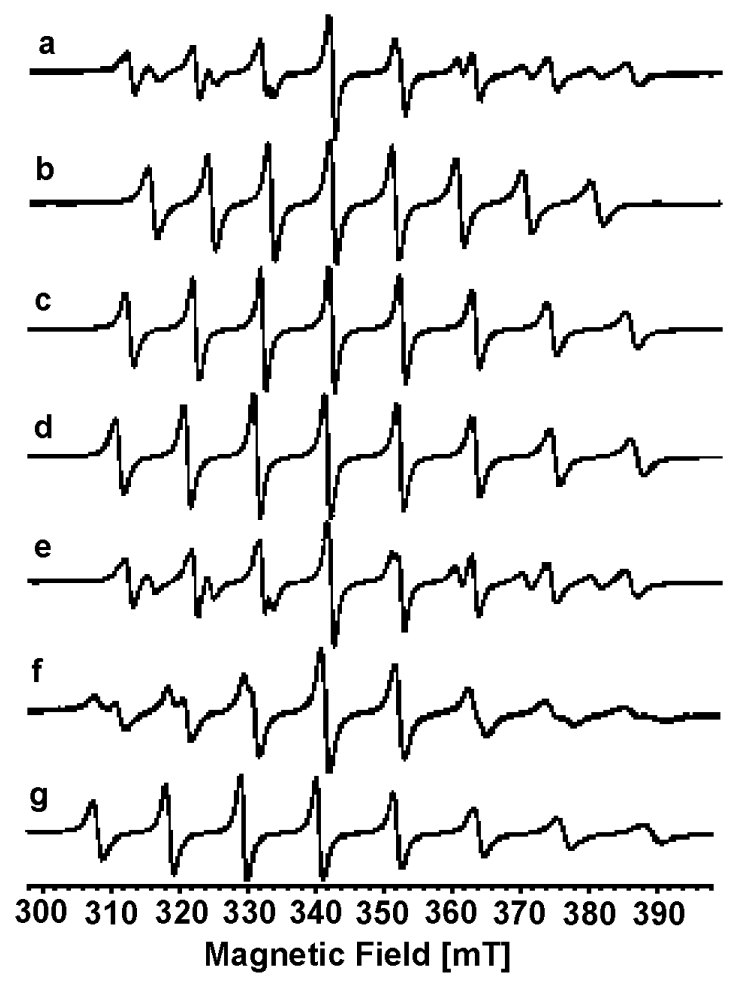

Fig. 10 Ambient-temperature EPR spectra show that $\left[\mathrm{VO}(\text { malto })_{2}\right]$ forms adducts with $\mathrm{H}_{2} \mathrm{O}$. Reprinted with permission from ref. [103]. Copyright (C) 1996 American Chemical Society.

Vanadium(V) alkoxides of acac [98] and pyridones [104] have been reported. The vanadium(V) complexes for both the acac and the maltol ligand favor only the formation of complexes with an incoming solvent molecule cis to the oxo group $[98,104]$. The vanadium(V)-acac system while maintaining the alkoxide cis to the oxo unit, can form mononuclear, dinuclear, trinuclear, and tetranuclear compounds in solution as shown in Scheme 1. These studies were based on the less frequently used precursor $\left[\mathrm{VO}_{2}\right.$ acac], first reported by Bartecki and Kaminski $[105,106]$. By substituting the ligand, often with a solvent molecule, it was possible to isolate complexes with different nuclear cores as shown in Scheme 1 [98]. The steric bulk of the isopropanol is sufficient to allow the isolation of monomeric complexes with $\left[\mathrm{VO}_{2}\right.$ acac $]$. Dissolving the $\left[\mathrm{VO}_{2} \mathrm{acac}\right]$ in a simple alcohol such as methanol allows the isolation of a dinuclear species and tetranuclear species with the methoxide bridging. When no cosolvent is used, the isolation of the dinuclear complex with a higher V:alkoxide ratio was achieved. The addition of acetonitrile as a cosolvent led to the isolation of a tetranuclear species with fewer alkoxide units per vanadium $(\mathrm{V})$ and the typical tetranuclear core cluster is formed. Finally, in the presence of a tridentate ligand, tris(hydroxymethyl)ethane, the cluster is capped so that a linear trinuclear core results. The vanadium $(\mathrm{V})$ alkoxides that form with acac deviate from the mono and dinuclear complexes observed with 1,2-diols. Aqueous studies show a much more limited reactivity pattern for vanadium(V) with acac (unpublished) or maltol [107] than the corresponding vanadium(IV) compounds. Although we are only now investigating the chemistry of simple alcohols with vanadium(IV), there is no evidence that vanadium(IV)-acac systems generate clusters [102] as in the corresponding vanadium(V)-acac system [98]. 


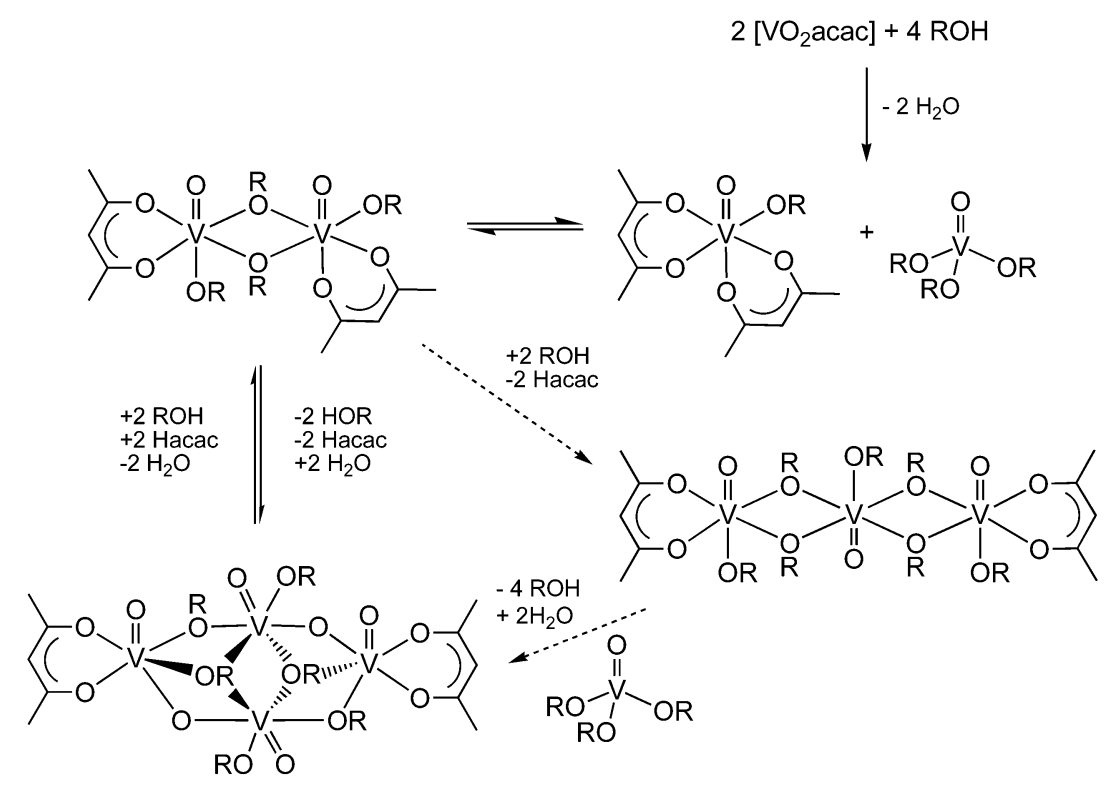

Scheme 1 Proposed relationships between mononuclear and oligomeric vanadium(V) species in organic solvents based on $\left[\mathrm{VO}_{2} \mathrm{acac}\right]$ as the starting material. Reprinted with permission from ref. [98]. Copyright (C) 1998 American Chemical Society.

Reactions with polydentate O-functional ligands have demonstrated a variety of reactivities. The Zubieta group has undertaken studies with the ligand tris(hydroxymethyl)ethane, and a range of decamers and other oxometalates have been capped with this ligand and structurally characterized [108-111]. These complexes are important not only because they document the electronic properties of such derivatives, but also because they show, for example, that a decamer, which is a very stable system in aqueous systems, readily undergoes substitution reactions on the oxometalate surface in the absence of water. Such reactivity is likely to be important for the catalytic properties that vanadium compounds exhibit. The Crans group has also examined reactions of tris(hydroxymethyl)ethane in organic solvents [112]. In nonaqueous solution, the chemistry of this system is equally diverse. In one case, this ligand shows the selective substitution of one alkoxide over another, Scheme 2 [112]. The Tracey group showed that in aqueous solution this ligand also forms a complex, but it is much less stable [58]. Indeed, these studies demonstrate the versatility of vanadium chemistry and build a framework on which the complex aqueous systems of biological relevance can be understood. For example, the Salifoglou group have characterized in detail a series of vanadium(V)-citrate complexes [113], and compared the isolated solid-state species with those observed in solution $[114,115]$. The reactivity and presumed selectivity of the reactions of these clusters may prove to follow similar guidelines and selectivities as those observed in the complex shown in Scheme 2. Such studies could point to how these very intriguing vanadiumcitrate complexes react with metabolites and proteins under physiological conditions. 


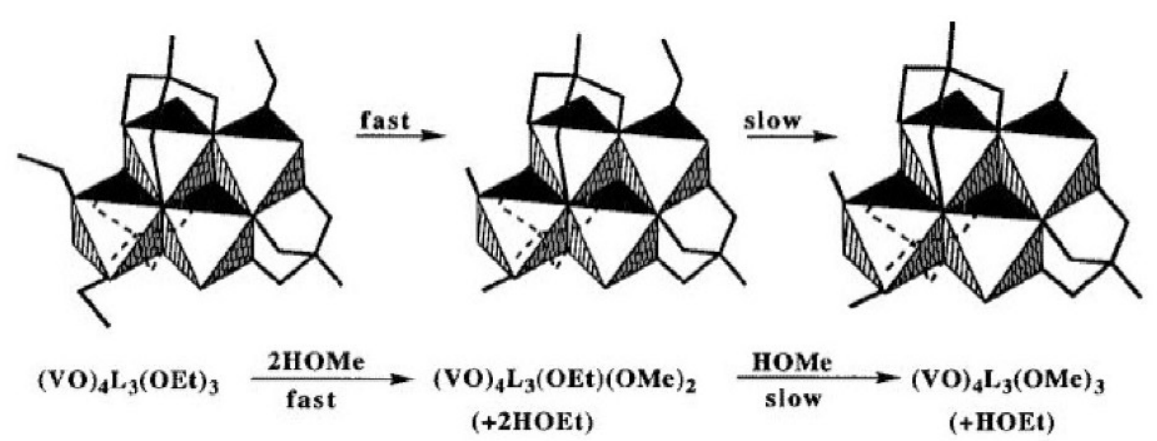

Scheme 2 Specific alkoxide exchange reactions on the surface of a tetranuclear vanadium(V) alkoxide $\left(\left[\mathrm{V}_{4} \mathrm{O}_{4}\left\{\left(\mathrm{OCH}_{2}\right)_{3} \mathrm{CCH}_{3}\right\}_{2}\left(\mathrm{OCH}_{3}\right)_{6}\right]\right)$ in the presence of $\mathrm{CH}_{3} \mathrm{OH}$. Reprinted with permission from ref. [116]. Copyright (C) 1997 American Chemical Society.

The synthetic utility of vanadium(V) alkoxides as electron-transfer reagents have been explored for many years by the Hirao and Conte groups [6,7]. The versatility of these compounds in organic syntheses continues to be explored. As recently reported by the Rosenthal group, vanadium(V)-alkoxide chemistry now shows potential utility in polymer catalysis [91,92]. These studies demonstrated coordination chemistry of mixed vanadium $(\mathrm{V})$ chloro-alkoxides with four-, five-, and six-coordinate vana$\operatorname{dium}(\mathrm{V})$ complexes with bridging chloro groups [92]. Since the catalytic efficiency of systems with different coordination chemistries appears to be similar, this variation in the vanadium coordination number may not impact the catalytic mechanism in these systems. Of course, such a conclusion assumes that the mononuclear and dinuclear forms of these complexes fail to interconvert, which, based on the available information for similar systems, may not be a realistic expectation.

\section{HOW DO VANADIUM COMPLEXES REACT IN AQUEOUS SOLUTION?}

How vanadium complexes react in water depends on the complexes' thermodynamic stability and how fast and by what mechanism they hydrolyze and/or undergo redox chemistry. Data on the thermodynamic stability of vanadium(V) complexes in water has been determined for a wide range of systems, and this information provides a good starting point for the consideration of the kinetic and mechanistic properties of vanadium complexes. The summary presented here will focus on studies of vanadium(V) and (IV) coordination complexes in aqueous solution.

Kinetic studies, using rapid mixing techniques, of vanadium(V) complexes over a wide $\mathrm{pH}$ range are not common, in part because many of these complexes are colorless, and in part because the complexes have a limited $\mathrm{pH}$ stability as shown in speciation studies. Furthermore, there are relatively few examples of systems that have been investigated using a range of techniques and where intermediates of vanadium(V) complexes have been characterized by spectroscopy. Most kinetic studies have been carried out in acidic aqueous solutions, where the major vanadium(V) species is the $\mathrm{VO}_{2}{ }^{+}$(presumably $\left.\left[\mathrm{VO}_{2}\left(\mathrm{H}_{2} \mathrm{O}\right)_{4}\right]^{+}\right)$cation $[117,118]$. Ligand-exchange reactions have also been investigated using NMR spectroscopy [18,119], and for this class of compounds, NMR-based methods have been more informative than absorption spectroscopy as illustrated in Fig. 11 [44,54,60,80].

${ }^{1} \mathrm{H}$ and ${ }^{13} \mathrm{C}$ NMR spectroscopy have been very useful techniques for studying the solution structure of vanadium(V) complexes [12,14,16,17,41,44,60,72,74,75,80,88,90,95,114]. Both 1D [54] and 2D NMR methods have been very informative with regard to the formation of reaction intermediates $[44,120]$. For example, the intermolecular exchange between free ligand and complexed ligand can be observed in an EXSY experiment as indicated by the solid lines in Fig. 11. In addition, the intramolecular exchange of the coordinated hydroxymethyl arm with one of the free hydroxymethyl arms in the complex that forms between vanadate and tricine ( $N$-[tris(hydroxymethyl)methyl]glycine) is ob- 


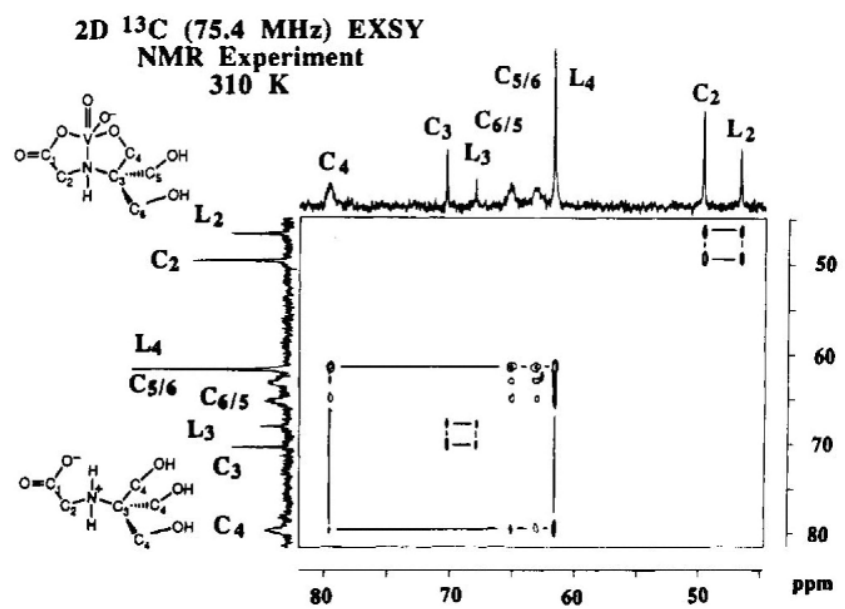

Fig. $11 \mathrm{~A} 2 \mathrm{D}{ }^{13} \mathrm{C}$ EXSY NMR spectrum recorded at $75.4 \mathrm{MHz}$ at $310 \mathrm{~K}$ of a solution containing $412 \mathrm{mM}$ vanadate and $500 \mathrm{mM}$ Tricine ligand at $\mathrm{pH}$ 7.2. This solution shows exchange between the $398 \mathrm{mM}$ of $\left[\mathrm{VO}_{2}(\text { tricine) }]^{-}\right.$in solution and the $102 \mathrm{mM}$ of free tricine as indicated by the line connecting diagonal points with off-diagonal points. Intramolecular exchange between free and coordinated hydroxyl arms is indicated by the much lower intensity offdiagonal signals. Reprinted with permission from ref. [44]. Copyright (C) 1991 American Chemical Society.

served as the additional off-diagonal signals shown in Fig. 11. This method has been used to follow the conversion of one enantiomeric vanadium $(\mathrm{V})$ form to the other by observation of an off-diagonal signal. This is observed even though the enantiomeric forms of the complexes have identical chemical shifts [55].

Few kinetic studies have been carried out on complexes at neutral $\mathrm{pH}$ when the major vana$\operatorname{dium}(\mathrm{V})$ species in solution is $\mathrm{H}_{2} \mathrm{VO}_{4}{ }^{-}$or $\mathrm{HVO}_{4}{ }^{2-}$ at lower concentrations and $\mathrm{V}_{4} \mathrm{O}_{12}{ }^{4-}$ at higher concentrations. EXSY spectroscopy can be used to obtain quantitative information and accordingly can be used to determine approximate rate constants. A comparison of a series of different vanadium(V) complex formation reactions was made possible by using EXSY spectroscopic measurements and the normalization of rate constants to $25{ }^{\circ} \mathrm{C}$ (summarized in Table 1) [44]. Although the reactions considered are very different and include vanadate dimerization, complex formation with mono- and bidentate ligands, and complex formation with an enzyme, all the rate constants were observed to be of approximately the same magnitude. The observation that the rate constants for all these complexes lie within the narrow range of $(0.8-5) \times 10^{4} \mathrm{M}^{-1} \mathrm{~s}^{-1}$ suggests that these reactions near neutral $\mathrm{pH}$ are governed by a dissociative mechanism [44]. Since at neutral $\mathrm{pH}$ the ligand exchange will require several protontransfer steps before ligand exchange can occur, a direct comparison of these substitution reactions with those at low $\mathrm{pH}$, when $\mathrm{VO}_{2}{ }^{+}$is the vanadium species, may not be appropriate. A detailed comparison of the observed rate constants for the reactions studied at various $\mathrm{pH}$ regions still needs to be carried out. 
Table 1 Second-order rate constants for vanadate complex formation near neutral $\mathrm{pH}$ [44].

\begin{tabular}{llrrl}
\hline Ligand & \multicolumn{1}{c}{ Complex } & $\begin{array}{r}\text { Rate constant } \\
\left(\mathrm{M}^{-1} \mathrm{~s}^{-1}\right)\end{array}$ & $\begin{array}{r}\text { Temp } \\
\left({ }^{\circ} \mathrm{C}\right)\end{array}$ & Reference \\
\hline Vanadate monomer & $\mathrm{H}_{2} \mathrm{VO}_{4}{ }^{-}-\mathrm{HVO}_{4}{ }^{2-\mathrm{a}}$ & $3.1 \times 10^{4}$ & 25 & {$[28]$} \\
& & $2 \times 10^{4}$ & 25 & {$[36]$} \\
Alizarin $\left(\mathrm{H}_{2} \mathrm{~A}\right)$ & $\mathrm{H}_{2} \mathrm{VO}_{4}{ }^{-}-\mathrm{HA}$ & $2.8 \times 10^{4}$ & 25 & {$[121]$} \\
Tricine & $\mathrm{H}_{2} \mathrm{VO}_{4}{ }^{-}-\mathrm{Tricine}(0,1,1)$ & $0.76 \times 10^{4}$ & 25 & {$[44]$} \\
EDTA & $\mathrm{H}_{2} \mathrm{VO}_{4}{ }^{-}-\mathrm{H}_{2}$ EDTA $^{2-}$ & $3.2 \times 10^{4}$ & 25 & {$[121]$} \\
Na,K-ATPase & $\mathrm{H}_{2} \mathrm{VO}_{4}{ }^{-}-$ATPase & $5.2 \times 10^{4}$ & 37 & {$[122]$} \\
& & $2.9 \times 10^{4}$ & 25 & Estimated $^{\mathrm{b}}$ \\
\hline
\end{tabular}

${ }^{\mathrm{a}}$ The product of the dimerization is $\mathrm{HV}_{2} \mathrm{O}_{7}{ }^{3-}$.

${ }^{b}$ The rate constant at $25^{\circ} \mathrm{C}(298 \mathrm{~K})$ was calculated with use of the equation $k_{2}=\left(k_{1} \mathrm{~T}_{2} / \mathrm{T}_{1}\right) \mathrm{e}^{\left[\Delta G^{\dagger} / \mathrm{R}\left(1 / \mathrm{T}_{1}-1 / \mathrm{T}_{2}\right)\right]}$.

In aqueous solutions, complex formation with redox active ligands is often followed by electrontransfer reactions [123-128]. Kustin documented the electron-transfer reactions for a series of vanadium compounds including catechols [129], aromatic diols [127], and ascorbate [128]. Other groups have carried out studies on amino polycarboxylate systems [123-125,130] as well as on carbohydrates [131]. Many of the electron-transfer reactions are presumed to take place by inner-sphere electrontransfer processes, in part because systems characterized in the greatest detail show intermediate vana$\operatorname{dium}(\mathrm{V})$ complexes. However, several examples of outer-sphere electron-transfer processes have been reported [124,132].

An intermediate vanadium $(\mathrm{V})$ complex forms with ascorbate in the presence of vanadate and is observed at $425 \mathrm{~nm}$ before the vanadium is reduced (Fig. 12). The Crans group has recently collaborated with the Johnson group in further characterizing the reduction of the vanadium $(\mathrm{V})$ by ascorbate [133]. The new studies show that the reaction between ascorbate and vanadium( $\mathrm{V})\left(\mathrm{VO}_{2}^{+}\right)$, characterized by Kustin [128] takes place over a much wider $\mathrm{pH}$ range. More importantly, however, the studies at higher ascorbate concentrations found evidence for a second electron-transfer process [133] in competition with the inner-sphere electron-transfer process reported previously [128]. Studies using EPR spectroscopy were carried out and supported a mechanism possibly involving an outer-sphere electrontransfer reaction. We find that ascorbate is competent to reduce vanadate at neutral $\mathrm{pH}$ in contrast to an earlier report [134]. Our evidence includes the appearance of EPR signals, which we and others assign to a vanadium(IV)-ascorbate complex and a complex with the oxidized ascorbate product $[133,135,136]$. 


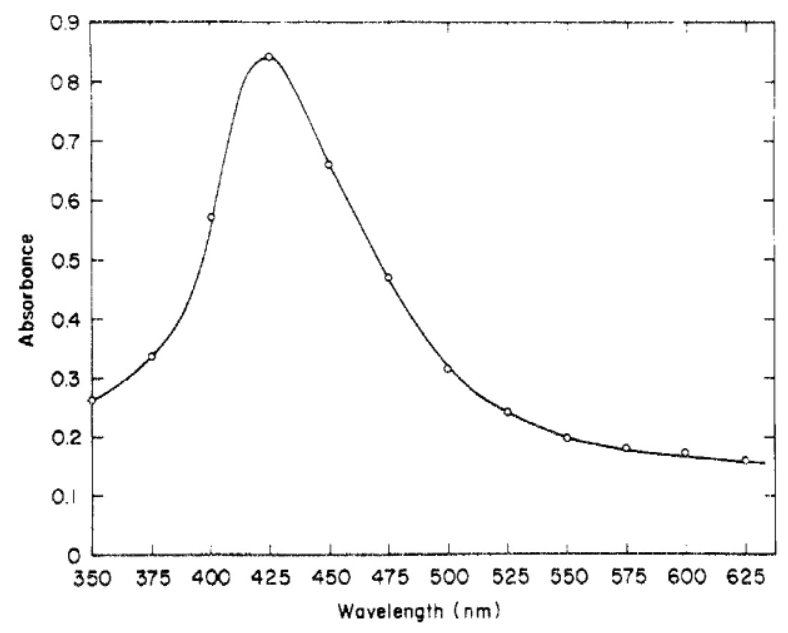

Fig. 12 The absorbance spectrum of the vanadium(V)-ascorbate complex before reduction of the vanadium(V) and oxidation of the ascorbate [128]. Reprinted with permission from ref. [128]. Copyright ( 1973 American Chemical Society.

A study by the Orvig group on the reduction of $\left[\mathrm{VO}_{2}(\text { malto })_{2}\right]^{-}$by ascorbate and reduced glutathione at $\mathrm{pH} 7.45$ was reported and showed pseudo-first-order kinetics when the reductant was present in large excess [137]. Examples of systems in which vanadium species in different oxidation states react with each other have also been reported [138].

Information on the ligand exchange of vanadium(IV) compounds has been obtained using a range of techniques [139-141]. Three types of oxygen ligands on the vanadium(IV) with different substitution rates have been identified $[139,140]$. Although early studies provided data that suggested an associative mechanism may be in effect for these types of systems $[118,142]$. Kustin and coworkers reexamined these studies, and when they included the deprotonation constant in their considerations, all the rate constants approached each other consistent with a dissociative mechanism [143]. It is now generally accepted that a dissociative mechanism is involved in substitution reactions in vanadium(IV) systems. Studies of anation reactions with a series of vanadium(IV) amino polycarboxylic acid complexes have been reported [118]. Formation of the $\left[\mathrm{VO}(\text { malto })_{2}\right]$ complex has also been described at $\mathrm{pH} 7$ [144], and this study as well as that with $\left[\mathrm{VO}(\text { dipic- } \mathrm{OH})\left(\mathrm{H}_{2} \mathrm{O}\right)_{2}\right]^{-}$show that these are equilibrium systems (eq. 4) [68]. In [ $\mathrm{VO}($ dipic-OH $\left.)\left(\mathrm{H}_{2} \mathrm{O}\right)_{2}\right]^{-}$, the ratio $k_{\mathrm{f}} / k_{\mathrm{r}}$ provides an expression for the $K_{\text {eq }}$, which decreases with increasing $\mathrm{pH}$ (Table 1) [68]. The increase in the thermodynamic stability under more acidic conditions is counterintuitive since a protonated ligand would be expected to be a poorer ligand. As seen from Table 2, the decreased stability at high $\mathrm{pH}$ is due to the increase in the dissociation rate constant [68]. The $\mathrm{p} K_{\mathrm{a}}$ of the hydroxyl group on coordinated dipic-OH ligand ranges from 4 to 5 and deprotonation of the $\mathrm{OH}$ group significantly decreases the ligand's ability to remain coordinated to the vanadium center as has been noted previously [66].

$$
\mathrm{d}\left[\mathrm{VO}(\text { dipic-OH })\left(\mathrm{H}_{2} \mathrm{O}\right)_{2}\right] / \mathrm{d} t=k_{\mathrm{f}}\left[\mathrm{VO}^{2+}{ }_{\text {aq }}\right][\text { dipic-OH }]+k_{\mathrm{r}}
$$


Table 2 Kinetic data for $\mathrm{VO}^{2+}$ reacting with $\mathrm{H}_{2}$ dipic-OH at $25^{\circ} \mathrm{C}$ and in $0.40 \mathrm{M} \mathrm{KCl}$ [68].

\begin{tabular}{lccr}
\hline $\mathrm{pH}$ & $k_{\mathrm{f}}\left(\mathrm{M}^{-1} \mathrm{~s}^{-1}\right)$ & $k_{\mathrm{r}}\left(\mathrm{s}^{-1}\right)$ & $K_{\mathrm{eq}}$ \\
\hline 5.0 & 2700 & 6.2 & 430 \\
4.1 & 2400 & 1.3 & 1850 \\
3.0 & 1500 & 1.0 & 1500 \\
2.5 & 1100 & 0.7 & 1570 \\
\hline
\end{tabular}

Interestingly, the forward second-order rate constant for complex formation for [VOdipic$\mathrm{OH}\left(\mathrm{H}_{2} \mathrm{O}\right)_{2}$ ] at pH 5 (see Table 2, [68]) is of the same order of magnitude as the rates obtained at neutral $\mathrm{pH}$ for the vanadium $(\mathrm{V})$ systems listed in Table 1 . Given the differences in the reactions required for ligand exchange on a vanadium complex in oxidation states +4 and +5 , such a similarity in rate constants would not be anticipated. As described above, both vanadium(IV) and (V) complexes undergo dissociative ligand substitution reactions, and more mechanistic information is needed with regard to the proton-transfer steps before loss of $\mathrm{H}_{2} \mathrm{O}, \mathrm{OH}^{-}$, or $\mathrm{O}^{2-}$ can take place. When such information is available the possibility that the rate constants for vanadium(IV) and (V) systems are truly similar can be addressed.

\section{WHAT ARE THE EFFECTS OF VANADIUM SPECIES IN BIOLOGICAL SYSTEMS?}

Two decades ago, all of the effects of vanadate were attributed to the action of the monomeric form of vanadate (reviewed in ref. [145]). This presumption was developed based on several interesting reports $[77,146,147]$. First, a vanadate-nucleoside was found to be a potent inhibitor for ribonuclease and the transition-state analogy between vanadate and phosphate was proposed [77]. Second, vanadate was then demonstrated to be as potent at inhibiting phosphatases as other oxoanions (e.g., arsenate and molybdate) [146]. Finally, the isolation of vanadate from a Sigma preparation of ATP was found to be a very potent inhibitor of the (Na,K)-ATPase enzyme [147] fueled a great deal of interest in the vanadiumphosphorus analogy. Although the existence of the oligomeric oxovanadates had been reported $[18,29,30,42]$, the possibility that the various forms of vanadium-compounds could have different biological effects had not been realized. Over a 10-year period, key discoveries were made which shaped our current thinking and understanding of the effects of vanadium compounds. Scientists are now aware that although vanadium species are rapidly interconverting, there is a large difference in their effects in biological systems depending on which species is present.

One of these discoveries was the recognition that alcohols will form esters in the presence of vanadate [20], and that these esters can be enzyme substrates [148], Figs. 13 and 14. For example, glucose-6-vanadate (Fig. 13) can substitute for glucose-6-phosphate in the oxidation reaction catalyzed by glucose-6-phosphate dehydrogenase (G6PDH) [148]. G6PDH was able to oxidize glucose much faster in the presence of vanadate than in its absence (Fig. 13) [148]. The proposed mechanism for this reaction involves formation of glucose-6-vanadate, binding of the substrate to G6PDH, catalytic oxidation of the substrate, release of the oxidized substrate, and finally, hydrolysis of the vanadate ester. Since this initial report, other enzymes have been found to accept vanadylated substrates as replacements for phosphorylated substrates [149] and cofactor analogs [150]. The cofactor analog NADV presumably has the vanadate is in the 2 ' position (Fig. 14) [150,151] and can substitute for NADP in enzyme reactions. The cofactor analog NADV has a more favorable $K_{\mathrm{m}} / k_{\text {cat }}$ than any other cofactor analog reported to date for G6PDH [150,151]. These studies demonstrate that vanadate derivatives can be effective substrates analogs in enzyme reactions. 


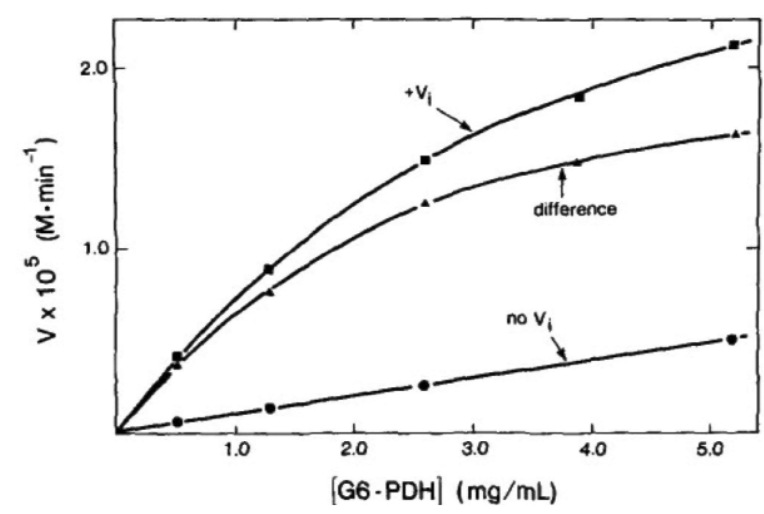

Fig. 13 Effect of different G6PDH concentrations on the rate of NADP reduction in the presences of $1.0 \mathrm{mM}$ glucose with and without $0.0156 \mathrm{mM}$ vanadate at $\mathrm{pH}$ 7.4. Reprinted with permission from ref. [148]. Copyright (C) 1985 the American Society for Biochemistry and Molecular Biology and Highwire Press.

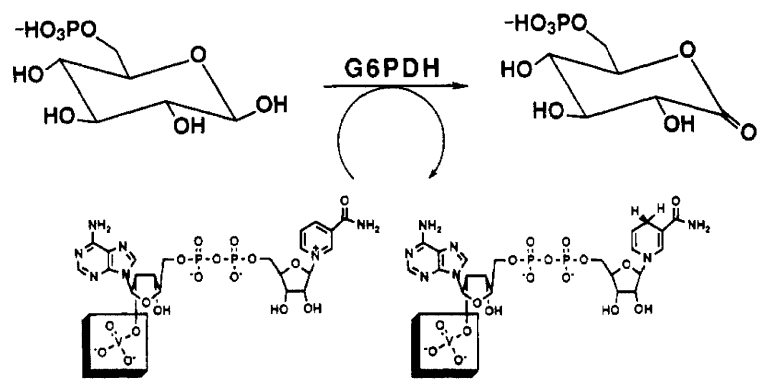

Fig. 14 Scheme showing the proposed reaction of glucose-6-phosphate with the cofactor analog NADV. The reaction is catalyzed by G6PDH and the initial products are proposed to be 6-phosphogluconate (or the corresponding lactone) and NADVH. Reprinted with permission from ref. [150]. Copyright (C) 1992 American Chemical Society.

A second discovery was that vanadate in the presence of hydrogen peroxide was found to be exceedingly potent in increasing protein tyrosine phosphorylation at the insulin receptor in tissue culture studies $[152,153]$. This observation was very important, in that all those interested in studies of the insulin-enhancing compounds*, realized that it was the peroxovanadium compound that exerted this effect and not simply the metal salt. A series of peroxovanadium compounds has since been investigated $[154,155]$. Which vanadium species is exerting the insulin-enhancing effect is still being discussed, although the emphasis has shifted from the peroxo compounds to simple coordination complexes [156-160]. An important ongoing issue concerns whether the ligand's sole role is to effect absorption of the vanadium ion and thus indirectly facilitate the insulin-enhancing of the vanadium ion in diabetic animals [156,157] or whether the ligand may actually take part of the mode of action of the vanadium compound by for example remain coordinated while the vanadium binds to the protein [158-160].

A third discovery was that the inhibitory effects of vanadate could readily arise from different oxovanadate species using the pentose phosphate shunt enzyme, 6-phosphogluconate dehydrogenase [161]. By correlating the enzyme reaction rates with the oxovanadate species, it was recognized that

\footnotetext{
*Initially, the effects observed with vanadate were described as additive to the effects observed with insulin, and the term insulinmimetic was used for some time. However, since then, investigative studies with a few compounds has demonstrated that the effect is insulin-enhancing and not insulin-mimetic. At this time, there is no doubt that some level of insulin is needed in order for these compounds to exert their maximum effect.
} 
vanadate monomer $\left(\mathrm{V}_{1}\right)$ was not the inhibiting species, as shown in Fig. 15. No linear relationships could be observed between enzyme inhibition and the concentration of the $V_{1}$ species as anticipated with inhibitors, Fig. 15a. In contrast, the observed inhibition correlated with the concentration of vanadate tetramer $\left(\mathrm{V}_{4}\right)$, as evidenced by the linear relationship shown in Fig. 15b [161]. Although these studies did not actually demonstrate that $\mathrm{V}_{4}$ was the active species, the studies did show that some combination of four vanadium atoms (a tetramer, two dimers, one dimer, and two monomers, etc.) was needed to show a correlation with the observed inhibition.
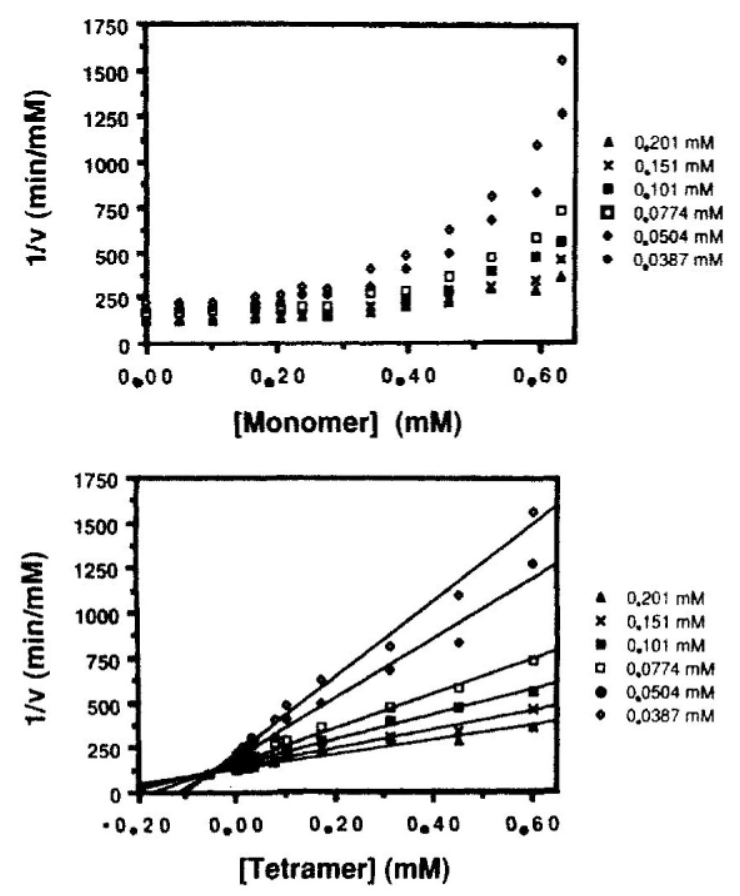

Fig. 15 Two Dixon plots showing the reciprocal rate obtained in the reaction of 6-phosphogluconate with NAD catalyzed by 6-phosphogluconate dehydrogenase from Torula yeast analyzed against two representative vanadium species in solution. The reciprocal rates are plotted as a function of the concentration of vanadium atoms found as monomeric vanadate $\left(\mathrm{V}_{1}\right)$ in $(\mathrm{a})$ and as tetrameric vanadate $\left(\mathrm{V}_{4}\right)$ in $(\mathrm{b})$. Reprinted with permission from ref. [150]. Copyright $\odot 1992$ American Chemical Society.

Vanadate and other phosphate analogs, including arsenate, molybdate, and tungstate, are commonly known inhibitors of phosphatases $[17,146,162]$. Since vanadate is a very potent inhibitor for phosphatases and other phosphorylases, significant amounts of inhibition are observed at submillimolar concentrations, and below the vanadate concentrations when oligomers appear in solution. In Fig. 16a, the correlation is shown of the inhibition of wheat germ acid phosphatase with $V_{1}$ [163]. Since the correlation is linear when plotting the reciprocal rate of substrate hydrolysis as a function of concentration of $\mathrm{V}_{1}$, the inhibition is attributed to the monomer. Thus, for phosphatases, it is generally safe to assume that the inhibiting species is $\mathrm{V}_{1}$. However, for some classes of phosphatases such as the serine threonine protein phosphatase, the observed inhibition is moderate, and millimolar concentrations of vanadate are needed to invoke inhibition. Human prostatic acid phosphatase is an example of a phosphatase that is less potently inhibited by vanadate [163]. Using 4-methylumbelliferyl phosphate as substrate, the observed inhibition could not simply be attributed to $V_{1}$, but required both the $V_{2}$ and $V_{1}$ concentration to explain all the observed enzyme inhibition, Fig. 16b. Studies with protein phosphatases showed that on treatment with peroxovanadate, the active site thiol residue is oxidized, reflecting irre- 

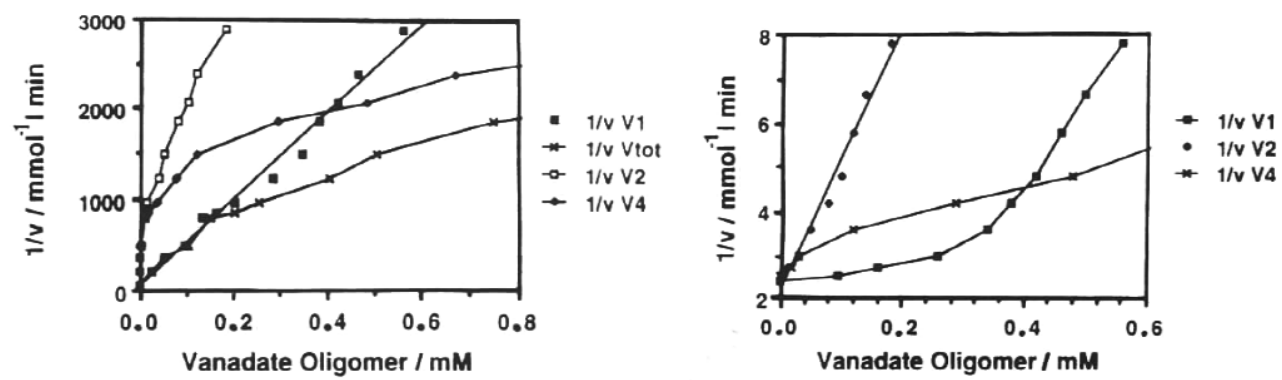

Fig. 16 The reciprocal rates of (a) wheat germ acid phosphatases and (b) human prostate acid phosphates catalyzed hydrolysis of $5 \mathrm{mM} 4$-methylumbelliferyl phosphate at $\mathrm{pH} 5.5$ and $0.20 \mathrm{M}$ acetate in the presence of various concentration of vanadate. The legend for (a) is $\mathrm{V}_{1}(\boldsymbol{\bullet}) ; \mathrm{V}_{2}(\square), \mathrm{V}_{4}(\boldsymbol{\bullet})$; and the total $\mathrm{V}$ concentration $\left(\mathrm{V}_{\text {tot }}\right)(*)$. The legend for (b) is $\mathrm{V}_{1}(\boldsymbol{\bullet}) ; \mathrm{V}_{2}(\bullet)$; and $\mathrm{V}_{4}(*)$. Reprinted with permission from ref. [163]. Copyright (@1989 American Society for Biochemistry and Molecular Biology and Highwire Press.

versible modification of the enzyme and possible modulation by redox [164,165]. Similar response was not observed with vanadate, a less oxidizing vanadium compound. Studies with phosphatases containing a binuclear metal cluster with redox active sites was undertaken, and evidence for redox chemistry under some conditions was obtained [166,167]. These fundamental studies with the enzymes, as well as the many X-ray structures available with vanadate in the active site, are important $[168,169]$ when attempting to understand the insulin-enhancing properties of vanadium compounds as well as how vanadium species can interact with proteins [160].

Based on the phosphate-vanadate analogy, the effects of vanadate have been investigated in tissue culture. Since the insulin-like action of vanadate was discovered in adipocytes [170,171], effects of this anion were tested in animals $[172,173]$. The ability of vanadium salts to lower elevated glucose levels in STZ-induced diabetic Wistar rats was reported in the mid-1980s [172,173]. $\mathrm{VOSO}_{4}$ is sold as a nutritional additive in food stores, and the therapeutic effects of $\mathrm{VOSO}_{4}$ and vanadate have been studied in diabetic human subjects [174-176]. The first studies in animals were followed by the Sakurai group, who showed that a wide range of vanadium(IV) complexes are able to lower elevated glucose levels in diabetic animals [177-179]. The effects of some of these compounds have been reviewed [180,181]. An in vitro assay to screen for vanadium compounds using the free fatty acid release has been developed and used with success [180,181]. In 1992, the McNeill-Orvig team reported blood-glucose-lowering effect of the bis(maltolato)oxovanadium(IV) ([VO(malto) $\left.)_{2}\right]$ ) complex [182], and this report was the first of a long series of detailed studies on the effects of [VO(malto $)_{2}$ ] [156]. As shown in Fig. 17, the glucose-lowering effects of this compound in diabetic animals does not extend to normal subjects. Phase I clinical trials with this compound have been completed, and details of this study will soon be reported. 


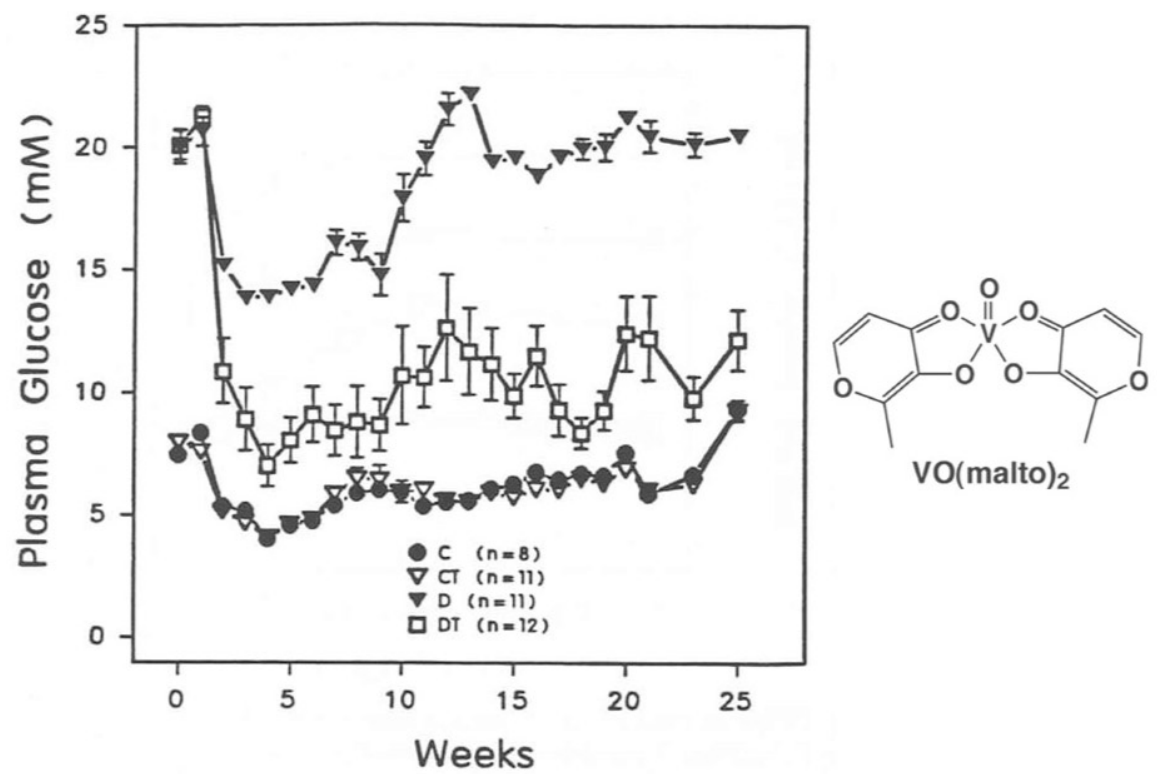

Fig. 17 Daily plasma glucose levels for the four treatment groups of male Wistar rats following chronic administration with bis(maltolato)oxovanadium(IV) $\left[\mathrm{VO}(\text { malto })_{2}\right]$ in the drinking water. The initial dose was 0.5 $\mathrm{mg} / \mathrm{mL}$ for 3 weeks and was then increased to $0.75 \mathrm{mg} / \mathrm{mL}$ for the remainder of the experimental period. There was no statistical difference between the C (control group) and CT (control treated group) animals at any time. From the initiation of treatment 1 week after STZ injection through to termination, group D (diabetic group) had significantly higher plasma glucose levels than group C. Reduction in plasma glucose levels in DT (diabetic treated) animals occurred within $24 \mathrm{~h}$ and was fully stable by week 2 of treatment. Reprinted with permission from ref. [183]. Copyright (C) 1993 National Research Council Research Press (NRC Research Press).

The Crans group initially got involved in this area by asking simple questions relating to the specific chemistry of the vanadium compounds. The possibility that simple ligands can be used was investigated in a collaboration with the Brichard group, where the $\left[\mathrm{VO}(\mathrm{acac})_{2}\right]$ complex was found to show very similar effects to the insulin-enhancing agent $\left[\mathrm{VO}\left(\right.\right.$ malto $\left._{2}\right][184]$. The possibility that vanadium compounds in oxidation state +5 could be active was demonstrated when Crans and Greco showed that a $\mathrm{NH}_{4}\left[\mathrm{VO}_{2}\right.$ dipic] was effective in diabetic cats in lowering blood glucose levels [185]. This work was substantiated with studies in the STZ-induced diabetic Wistar rat model system as shown in Fig. 18, documenting that several vanadium(V) compounds are effective in lowering blood glucose [68]. 


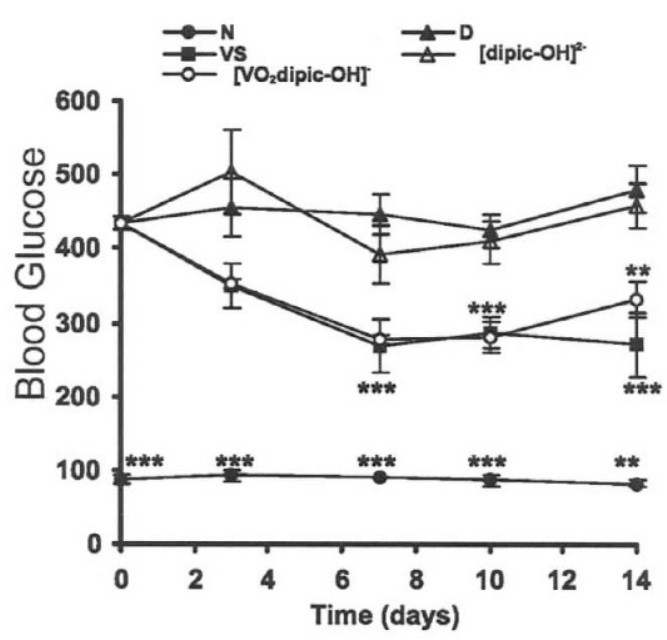

Fig. 18 The effect of $\left[\mathrm{VO}_{2} \text { dipic-OH] }\right]^{-}$on hyperglycemia in Wistar rats with STZ-induced diabetes. Compounds were administered in the drinking water for the following groups normal, $n=3(\bullet)$, untreated diabetic, $n=5(\bullet)$, $\mathrm{VOSO}_{4}$-treated diabetics, $n=5(\boldsymbol{\square})$, and $\left[\mathrm{VO}_{2} \text { dipic-OH] }\right]^{-}$treated diabetics, $n=8(\bigcirc)$. The concentration of compound in the drinking water was varied from 1.6 to $3.3 \mathrm{mM}$ to slowly bring the animals to the final treatment level during the first week and so that the amounts of $\mathrm{V}$ ingested $\mathrm{kg}^{-1}$ per day would be between 1 and $2 \mathrm{mmol}$. Data are presented as the mean $\pm \mathrm{SEM} * * \mathrm{P} \leq 0.01$ vs. diabetic, $* * * \mathrm{P} \leq 0.001$ vs. diabetic. Reprinted with permission from ref. [68]. Copyright @ 2003 Elsevier.

Despite many attempts, it is still difficult to describe how the vanadium compounds act in biological systems. The problem is exacerbated by the fact that observations in tissue culture do not always accurately reflect responses in animals. No doubt, the action of vanadium compounds in animal model systems is much more complex than in tissue culture. Unfortunately, since responses at the cellular level are often different when examining the effects in the cell culture and in the animals, tissue culture studies must involve close association with studies probing the effects in animal model systems. For example, the Willsky group has found that vanadium compounds protect against diabetes-induced apoptosis in muscle, whereas in cell culture studies these same compounds induce apoptosis (Willksy, Crans, unpublished). The Sakurai group, who were able to follow the metabolism of the vanadium compounds in blood, presented a recent and very exciting development. These studies show that vanadium compounds undergo a variety of conversions [186], some of which can be understood by speciation analysis [187]. The Sakurai group has been successful in demonstrating that ligand substitution is important and can fine-tune the insulin-enhancing properties of the complexes [181].

In collaboration with the Willsky group, the Crans group has studied the effects of vanadium compounds on gene expression using DNA microarray analysis [188]. The animals chosen for the gene array studies with $\mathrm{VOSO}_{4}$ as the vanadium compound were male Wistar rats with STZ-induced diabetes. In these animals, vanadium treatment alleviated both diabetic hyperglycemia and hyperlipidemia as monitored by a lowering of elevated blood glucose and serum cholesterol, triglyceride, and free fatty acids. In these studies, $40 \%$ of diabetes-induced changes in gene expression were corrected by oral treatment with vanadyl sulfate. Among this group of genes, the major gene group was lipid metabolism (Table 3). In addition, significant numbers of genes from oxidative stress pathways and diabetes-related signal transduction pathways were also identified as having corrected gene expression as a result of vanadium compound treatment. 
Table 3 Selected genes identified with diabetes-induced changes in gene expression in rat skeletal muscle corrected by oral administration of $\mathrm{VOSO}_{4}$ [188].

\begin{tabular}{|c|c|c|c|}
\hline \multicolumn{2}{|c|}{ Classification and gene description } & $\begin{array}{l}\text { Mean fold } \\
\text { change: } \\
\text { diabetic vs. } \\
\text { normal }\end{array}$ & $\begin{array}{l}\text { Mean fold } \\
\text { change: } \\
\mathrm{VOSO}_{4} \text {-treated } \\
\text { diabetic vs. } \\
\text { diabetic }\end{array}$ \\
\hline \multicolumn{4}{|l|}{ Up-regulated by diabetes } \\
\hline Lipid metabolism genes & $\begin{array}{l}\text { 2,4-Dienoyl-CoA reductase } \\
\text { Mitochondrial 3-hydroxy-3-methylglytaryl- } \\
\text { CoA synthase } \\
\text { Hormone-sensitive lipase } \\
\text { Lipoprotein lipase } \\
\text { Fatty acid binding protein } 4 \\
\text { Fatty acid translocase/CD36 } \\
\text { Aquaporin } 7 \\
\text { Carnitine palmitoyltransferase I } \\
\text { Apolipoprotein E }\end{array}$ & $\begin{array}{r}3.46 \\
7.46 \\
\\
2.64 \\
1.84 \\
10.41 \\
4.96 \\
2.46 \\
2.04 \\
2.83\end{array}$ & $\begin{array}{r}-4.44 \\
-10.27 \\
-1.87 \\
-1.99 \\
-1.54 \\
-3.68 \\
-2.22 \\
-2.13 \\
-3.94\end{array}$ \\
\hline Oxidative stress-related genes & $\begin{array}{l}\text { Gluthathione } S \text {-transferase Yb subunit }{ }^{\mathrm{a}} \\
\text { Glutathione } S \text {-transferase M5 } \\
\text { Metallothionein- } 2 \text { and metallothionein- } 1 \text { genes }^{\mathrm{a}} \\
\text { Lysyl oxidase }\end{array}$ & $\begin{array}{l}4.32 \\
2.68 \\
2.66 \\
3.18\end{array}$ & $\begin{array}{l}-2.69 \\
-4.17 \\
-2.95 \\
-3.58\end{array}$ \\
\hline Signal transduction genes & $\begin{array}{l}\text { Cbp/p300-Interacting transactivator } \\
\text { Pineal specific PG25 } \\
\text { PHAS-I } \\
\text { Ras-related protein (rad) } \\
\text { Cardiac adriamycin responsive protein (CARP) } \\
\text { RRRLIF1 R.rattus RL/IF-1 } \\
\text { Muscle LIM protein }\end{array}$ & $\begin{array}{r}2.83 \\
2.73 \\
3.94 \\
2.69 \\
11.00 \\
2.46 \\
4.14\end{array}$ & $\begin{array}{l}-2.14 \\
-4.03 \\
-5.46 \\
-4.17 \\
-7.06 \\
-3.43 \\
-3.18\end{array}$ \\
\hline Protein degradation genes & $\begin{array}{l}\text { Cathepsin } \\
\text { Lysozyme } \\
\text { C4 complement protein } \\
\text { Complement protein } \mathrm{C} 1 \mathrm{q} \text { beta chain }\end{array}$ & $\begin{array}{l}4.78 \\
7.11 \\
7.52 \\
6.28\end{array}$ & $\begin{array}{l}-2.10 \\
-2.89 \\
-2.51 \\
-3.25\end{array}$ \\
\hline Down-regulated by diabetes & 5-Aminolevulinate synthase & -2.66 & 2.87 \\
\hline
\end{tabular}

a'Genes whose product level or product has been specifically shown to be related to treatment with a vanadium compound.

Indeed, in collaboration with the Willsky group, the Crans group has embarked on a comparative study that investigates the effects of ligand (unpublished), metal ion (unpublished), and metal ion oxidation state [69]. The team has obtained chemical, biochemical, biological, pharmacological, and genetic information on more than 20 compounds and their ligands. Through the analysis of the data generated for this compound profile, statistical analysis has identified traits in which chemical, biochemical, and biological data correlate with the effectiveness in lowering of elevated blood glucose and lipid levels. These results have provided parameters that have led the team to investigate vanadium compounds that do not show similar profiles to those compounds, which are effective in animals. We found that the redox properties of the compounds seemed to show a very strong correlation with their effectiveness in the animal model system. All the vanadium compounds investigated underwent irreversible aqueous redox chemistry as determined by cyclic voltammetry. The hypothesis was developed 
that a vanadium compound with reversible redox chemistry would not show effectiveness as an insulinenhancing agent in vivo. As a result, the team identified amavadin-like compounds that, based on this criteria, would not be expected to be effective insulin-enhancing agents. The Crans/Willsky team tested one such compound in STZ-induced diabetic Wistar rats, and the results clearly show that the positive control, $\mathrm{VOSO}_{4}$, had the blood-glucose-lowering effect observed previously, whereas the amavadin-like compound did not show any anti-diabetic effects. We have, therefore, been the first group to successfully identify properties needed for insulin-enhancing effects and chose a vanadium compound that showed the predicted lack of activity in an animal model system (Willsky, Crans, unpublished). The details of these studies will be reported in due course.

\section{SUMMARY}

As described above, the changes in the general outlook and understanding of vanadium chemistry for the past two decades have been dramatic. Thus, although many interesting areas of vanadium chemistry have not been described in this review, the fundamental questions and approaches taken in the areas described have affected other areas of vanadium chemistry. Indeed, I hope that our success will inspire others to venture into vanadium chemistry. Focusing on a fundamental understanding of the species in solution, their structure and properties has had a very beneficial effect on understanding the effects different species can have in a biological system.

\section{ACKNOWLEDGMENTS}

DCC thanks all her coworkers and collaborators for their work and insights. Without all these individuals, named in the joint publications cited in this review, the studies would not have been possible. DCC also thanks NIH and NSF for funding. DCC thanks Jason J. Smee for his assistance in the preparation of this manuscript. DCC also thanks Stephanie Starck, Shamera Loose, Gail R. Willsky, Michael D. Johnson, Patricia A. Wilkins, Alan S. Tracey, Christopher R. Roberts, and Dieter Rehder for reading and improving this manuscript.

\section{REFERENCES}

1. N. D. Chasteen. Vanadium in Biological Systems: Physiology and Biochemistry, Kluwer Academic, Boston (1990).

2. M. J. Gresser and A. S. Tracey. In Vanadium in Biological Systems: Physiology and Biochemistry, N. D. Chasteen (Ed.), pp. 63-79, Kluwer Academic, Boston (1990).

3. D. Rehder. Angew. Chem., Int. Ed. Engl. 30, 148-167 (1991).

4. A. Butler, M. J. Clague, G. Meister. Chem. Rev. 94, 625-638 (1994).

5. H. Sigel and A. Sigel. Metal Ions in Biology, Marcel Dekker, New York (1995).

6. T. Hirao. Chem. Rev. 97, 2707-2724 (1997).

7. V. Conte, F. Di Furia, S. Moro. J. Phys. Org. Chem. 9, 329-336 (1996).

8. J. O. Nriagu. Vanadium in the Environment. Part 1: Chemistry and Biochemistry, John Wiley, New York (1998).

9. J. O. Nriagu. Vanadium in the Environment. Part 2: Health Effects, John Wiley, New York (1998).

10. A. S. Tracey and D. C. Crans. Vanadium Compounds: Chemistry, Biochemistry, and Therapeutic Applications, American Chemical Society, Washington, DC (1998).

11. D. Rehder. Coord. Chem. Rev. 297-322 (1999).

12. V. Conte, O. Bortolini, M. Carraro, S. Moro. J. Inorg. Biochem. 80, 41-49 (2000).

13. A. S. Tracey. J. Inorg. Biochem. 80, 11-16 (2000).

14. C. D. Garner, E. M. Armstrong, R. E. Berry, R. L. Beddoes, D. Collison, J. J. A. Cooney, S. N. Ertok, M. Helliwell. J. Inorg. Biochem. 80, 17-20 (2000). 
15. H. Michibata, T. Uyama, T. Ueki, K. Kanamori. Microsc. Res. Technol. 56, 421-434 (2002).

16. W. Plass. Coord. Chem. Rev. 237, 205-212 (2003).

17. D. C. Crans, J. Smee, E. Gaidamauskas, L. Yang. Chem. Rev. 104, 849-902 (2004).

18. E. Heath and O. W. Howarth. J. Chem. Soc., Dalton Trans. 1105-1110 (1981).

19. O. W. Howarth and M. Jarrold. J. Chem. Soc., Dalton Trans. 503-506 (1978).

20. M. J. Gresser and A. S. Tracey. J. Am. Chem. Soc. 107, 4215-4220 (1985).

21. M. J. Gresser and A. S. Tracey. J. Am. Chem. Soc. 108, 1935-1939 (1986).

22. M. J. Gresser, A. S. Tracey, K. M. Parkinson. J. Am. Chem. Soc. 108, 6229-6234 (1986).

23. D. Rehder, C. Weidemann, A. Duch, W. Priebsch. Inorg. Chem. 27, 584-587 (1988).

24. W. Priebsch and D. Rehder. Inorg. Chem. 24, 3058-3062 (1985).

25. D. Rehder. Z. Naturforsch. 32b, 771-775 (1977).

26. M. T. Pope and B. W. Dale. Quart. Rev. Chem. Soc. 22, 527-548 (1968).

27. M. A. Habayeb and O. E. Hileman, Jr. Can. J. Chem. 58, 2255-2261 (1980).

28. M. P. Whittaker, J. Asay, E. M. Eyring. J. Phys. Chem. 70, 1005-1008 (1966).

29. L. Pettersson, B. Hedman, I. Andersson, N. Ingri. Chem. Scr. 22, 254-264 (1983).

30. L. Pettersson, I. Andersson, B. Hedman. Chem. Scr. 25, 309-317 (1985).

31. J. J. Cruywagen and J. B. B. Hyens. Polyhedron 10, 249-253 (1991).

32. J. J. Cruywagen, J. B. B. Heyns, A. N. Westra. Inorg. Chem. 35, 1556-1559 (1996).

33. J. J. Cruywagen and J. B. B. Heyns. Talanta 37, 741-744 (1990).

34. D. C. Crans and P. K. Shin. Inorg. Chem. 27, 1797-1806 (1988).

35. D. C. Crans, R. L. Bunch, L. A. Theisen. J. Am. Chem. Soc. 111, 7597-7607 (1989).

36. D. C. Crans, C. D. Rithner, L. A. Theisen. J. Am. Chem. Soc. 112, 2901-2908 (1990).

37. D. Rehder. Inorg. Chem. 27, 4312-4316 (1988).

38. C. Weidemann, W. Priebsch, D. Rehder. Chem. Ber. 122, 235-243 (1989).

39. K. Elvingson, M. Fritzsche, D. Rehder, L. Pettersson. Angew. Chem., Int. Ed. Engl. 48, 878-885 (1994).

40. K. Elvingson, D. C. Crans, L. Pettersson. J. Am. Chem. Soc. 119, 7005-7012 (1997).

41. C. F. G. C. Geraldes and M. M. C. A. Castro. J. Inorg. Biochem. 35, 79-93 (1989).

42. O. W. Howarth. Prog. NMR Spectrosc. 22, 453-483 (1990).

43. D. C. Crans, S. M. Schelble, L. A. Theisen. J. Org. Chem. 56, 1266-1274 (1991).

44. D. C. Crans, P. M. Ehde, P. K. Shin, L. Pettersson. J. Am. Chem. Soc. 113, 3728-3736 (1991).

45. A. S. Tracey and C. H. Leon-Lai. Inorg. Chem. 30, 3200-3204 (1991).

46. D. Rehder. Coord. Chem. Rev. 297-322 (1999).

47. L. Yang, A. La Cour, O. P. Anderson, D. C. Crans. Inorg. Chem. 41, 6322-6331 (2002).

48. A. S. Tracey, H. Li, M. J. Gresser. Inorg. Chem. 29, 2267-2271 (1990).

49. A. S. Tracey, M. J. Gresser, K. M. Parkinson. Inorg. Chem. 26, 629-638 (1987).

50. B. Galeffi and A. S. Tracey. Inorg. Chem. 28, 1726-1734 (1989).

51. D. C. Crans, A. D. Keramidas, S. S. Amin, O. P. Anderson, S. M. Miller. J. Chem. Soc., Dalton Trans. 2799-2812 (1997).

52. A. D. Keramidas, S. M. Miller, O. P. Anderson, D. C. Crans. J. Am. Chem. Soc. 119, 8901-8915 (1997).

53. P. C. Paul, S. J. Angus-Dunne, R. J. Batchelor, F. W. B. Einstein, A. S. Tracey. Can. J. Chem. 75, 183-191 (1997).

54. D. C. Crans, H. Holst, A. D. Keramidas, D. Rehder. Inorg. Chem. 34, 2524-2534 (1995).

55. D. C. Crans, F. Jiang, I. Boukhobza, I. Bodi, T. Kiss. Inorg. Chem. 38, 3275-3282 (1999).

56. A. S. Tracey, M. J. Gresser, S. Liu. J. Am. Chem. Soc. 110, 5869-5874 (1988).

57. A. S. Tracey and M. J. Gresser. Inorg. Chem. 27, 2695-2702 (1988).

58. A. S. Tracey and M. J. Gresser. Inorg. Chem. 27, 1269-1275 (1988).

59. J. S. Jaswal and A. S. Tracey. Can. J. Chem. 69, 1600-1607 (1991).

60. D. C. Crans, H. Chen, O. P. Anderson, M. M. Miller. J. Am. Chem. Soc. 115, 6769-6776 (1993). 
61. M. Fritzsche, K. Elvingson, D. Rehder, L. Pettersson. Acta Chem. Scand. 51, 483-491 (1997).

62. M. Mahroof-Tahir, A. D. Keramidas, R. B. Goldfarb, O. P. Anderson, M. M. Miller, D. C. Crans. Inorg. Chem. 36, 1657-1668 (1997).

63. D. C. Crans and I. Boukhobza. J. Amer. Chem. Soc. 120, 8069-8078 (1998).

64. M. A. Scialdone and A. I. Meyers. Tet. Lett. 35, 7533-5736 (1994).

65. D. C. Crans and L. Yang. Inorg. Chem. 39, 4409-4416 (2000).

66. T. Jakusch, W. Jin, L. Yang, T. Kiss, D. C. Crans. J. Inorg. Biochem. 95, 1-13 (2003).

67. D. C. Crans, L. Yang, J. A. Alfano, L.-H. Chi, W. Jin, M. Mahroof-Tahir, K. Robbins, M. M. Toloue, L. K. Chan, A. J. Plante, R. Z. Grayson, G. R. Willsky. Coord. Chem. Rev. 237, 13-22 (2003).

68. D. Crans, M. Mahroof-Tahir, M. Johnson, P. Wilkins, L. Yang, K. Robbins, A. Johnson, J. Alfano, M. Godzala, L. Austin, G. Willsky. Inorg. Chim. Acta 356, 365-378 (2003).

69. P. Buglyo, D. C. Crans, E. M. Nagy, R. L. Lindo, L. Yang, J. Smee, W. Jin, L.-H. Chi, M. E. Godzala, G. R. Willsky. Inorg. Chem. 44, 5416-5427 (2005).

70. C. N. Caughlan, H. M. Smith, K. Watenpaugh. Inorg. Chem. 5, 2131-2134 (1966).

71. W. Priebsch and D. Rehder. Inorg. Chem. 29, 3013-3019 (1990).

72. D. C. Crans, R. A. Felty, M. M. Miller. J. Am. Chem. Soc. 113, 265-269 (1991).

73. F. Hillerns and D. Rehder. Chem. Ber. 124, 2249-2254 (1991).

74. D. C. Crans, R. W. Marshman, M. S. Gottlieb, O. P. Anderson, M. M. Miller. Inorg. Chem. 31, 4939-4949 (1992).

75. F. Hillerns, F. Olbrich, U. Behrens, D. Rehder. Angew. Chem., Int. Ed. Engl. 31, 447-448 (1992).

76. J. Y. Kempf, B. Maigret, D. C. Crans. Inorg. Chem. 35, 6485-6494 (1996).

77. R. N. Lindquist, J. L. Lynn, Jr., G. E. Lienhard. J. Am. Chem. Soc. 95, 8762-8768 (1973).

78. C. H. Leon-Lai, M. J. Gresser, A. S. Tracey. Can. J. Chem. 74, 38-48 (1996).

79. T. W. Hambley, R. J. Judd, P. A. Lay. Inorg. Chem. 31, 343-345 (1992).

80. D. C. Crans, R. A. Felty, H. Eckert, N. Das. Inorg. Chem. 33, 2427-2438 (1994).

81. P. J. Toscano, E. J. Schermerhorn, C. Dettelbacher, D. Macherone, J. Zubieta. J. Chem. Soc., Chem. Commun. 933-934 (1991).

82. D. C. Crans, R. A. Felty, O. P. Anderson, M. M. Miller. Inorg. Chem. 32, 247-248 (1993).

83. K. Paulsen, D. Rehder, D. Thoennes. Z. Naturforsch. 33, 834-839 (1978).

84. D. C. Crans, H. Chen, R. A. Felty. J. Am. Chem. Soc. 114, 4543-4550 (1992).

85. R. A. Henderson, D. L. Hughes, Z. Janas, R. L. Richards, P. Sobota, S. Szafert. J. Organomet. Chem. 554, 195-201 (1998).

86. S. Mondal, S. Prasad Rath, S. Dutta, A. Chakravorty. J. Chem. Soc., Dalton Trans. 99-103 (1996).

87. S. Mondal, P. Ghosh, A. Chakravorty. Ind. J. Chem. 35A, 171-173 (1996).

88. K. K. Rajak, S. P. Rath, S. Mondal, A. Chakravorty. Inorg. Chem. 38 (14), 3283-3289 (1999).

89. A. Sreedhara, C. P. Rao, B. J. Rao. Carbo. Res. 289, 39-53 (1996).

90. G. Asgedom, A. Sreedhara, J. Kivikoski, J. Valkonen, E. Kolehmainen, C. P. Rao. Inorg. Chem. 35, 5674-5683 (1996).

91. E. C. E. Rosenthal and F. Z. Girgsdies. Z. Anorg. Allg. Chem. 628, 1917-1920 (2002).

92. E. C. E. Rosenthal. Personal communication.

93. A. S. Tracey, J. S. Jaswal, M. J. Gresser, D. Rehder. Inorg. Chem. 29, 4283-4288 (1990).

94. W. J. Ray, Jr., D. C. Crans, J. Zheng, J. W. Burgner, II, H. Deng, M. Mahroof-Tahir. J. Am. Chem. Soc. 117, 6015-6026 (1995).

95. S. J. Angus-Dunne, R. J. Batchelor, A. S. Tracey, F. W. B. Einstein. J. Am. Chem. Soc. 117, 5292-5296 (1995).

96. T. M. Pope. In Comprehensive Coordination Chemistry, 2 (A. G. Wedd, Ed.), pp. 635-678, Elsevier, Amsterdam (2004).

97. O. W. Howarth and J. R. Trainor. Inorg. Chim. Acta 127, L27-L28 (1987). 
98. F. Jiang, O. P. Anderson, S. M. Miller, J. Chen, M. Mahroof-Tahir, D. C. Crans. Inorg. Chem. 37, 5439-5451 (1998).

99. N. M. Atherton, P. J. Gibbon, M. C. B. Shohoji. J. Chem. Soc., Dalton Trans. 2289-2290 (1982).

100. C. M. Guzy, J. B. Raynor, M. C. R. Symons. J. Chem. Soc. (A) 2791-2795 (1969).

101. R. L. Carlin and F. A. Walker. J. Am. Chem Soc. 87, 2128-2133 (1965).

102. S. S. Amin, K. Cryer, B. Zhang, S. K. Dutta, S. S. Eaton, O. P. Anderson, S. M. Miller, B. A. Reul, S. M. Brichard, D. C. Crans. Inorg. Chem. 39, 406-416 (2000).

103. G. R. Hanson, Y. Sun, C. Orvig. Inorg. Chem. 35, 6507-6512 (1996).

104. P. Caravan, L. Gelmini, N. Glover, F. G. Herring, H. Li, J. H. McNeill, S. J. Rettig, I. A. Setyawati, E. Shuter, Y. Sun, A. S. Tracey, V. G. Yuen, C. Orvig. J. Am. Chem. Soc. 117, 12759-12770 (1995).

105. A. Bartecki and J. Kaminski. Rocz. Chem. 47, 217-219 (1973).

106. A. Bartecki and J. Kaminski. Rocz. Chem. 49, 505-515 (1975).

107. K. Elvingson, A. González Baró, L. Pettersson. Inorg. Chem. 35, 3388-3393 (1996).

108. Q. Chen and J. Zubieta. Coord. Chem. Rev. 114, 107-167 (1992).

109. Q. Chen and J. Zubieta. J. Chem. Soc., Chem. Commun. 1180-1182 (1993).

110. M. I. Khan, Q. Chen, D. P. Goshorn, H. Hope, S. Parkin, J. Zubieta. J. Am. Chem. Soc. 114, 3341-3346 (1992).

111. I. Khan and J. Zubieta. In Progress in Organic Chemistry, K. D. Karlin (Ed.), pp. 29-50, John Wiley, New York (1995).

112. F. Jiang, O. P. Anderson, S. M. Miller, J. Chen, M. Mahroof-Tahir, D. C. Crans. Inorg. Chem. 37, 5439-5451 (1998).

113. M. Kaliva, T. Giannadaki, S. A. Salifoglou, C. P. Raptopoulou, A Terzis. Inorg. Chem. 41, 3850-3858 (2002).

114. M. Tsaramyrsi, M. Kaliva, A. Salifoglou, C. P. Raptopoulou, A. Terzis, V. Tangoulis, J. Giapintzakis. Inorg. Chem. 40, 5772-5779 (2001).

115. M. Tsaramyrsi, D. Kavousanaki, C. P. Raptopoulou, A. Terzis, A. Salifoglou. Inorg. Chim. Acta 320, 47-59 (2001).

116. D. C. Crans, F. Jiang, J. Chen, O. P. Anderson, M. M. Miller. Inorg. Chem. 36, 1038-1047 (1997).

117. S. Yamada, Y. Ukei, M. Tanaka. Inorg. Chem. 15, 964-967 (1976).

118. M. Nishizawa and K. Saito. Inorg. Chem. 19, 2284-2288 (1980).

119. I. Andersson, L. Pettersson, J. J. Hastings, O. W. Howarth. J. Chem. Soc., Dalton Trans. 3357-3361 (1996).

120. D. C. Crans, P. K. Shin, K. B. Armstrong. Mechanistic Bioinorganic Chemistry, ACS Symposium Series Vol. 246, pp. 303-328, American Chemical Society, Washington, DC (1995).

121. K. Kustin and D. L. Toppen. Inorg. Chem. 12, 1404-1407 (1973).

122. L. C. Cantley, Jr. Curr. Top. Bioenerg. 11, 201-237 (1981).

123. K. Saito and Y. Sasaki. Pure Appl. Chem. 60, 1123-1132 (1988).

124. M. Nishizawa, Y. Sasaki, K. Saito. Inorg. Chem. 24, 676-772 (1985).

125. B. Wang, Y. Sasaki, K. Okazaki, K. Kanesato, K. Saito. Inorg. Chem. 25, 3745-3749 (1986).

126. K. Kustin, C. Nicolini, D. L. Toppen. J. Am. Chem. Soc. 96, 7416-7420 (1974).

127. J. H. Ferguson and K. Kustin. Inorg. Chem. 18, 3349-3357 (1979).

128. K. Kustin and D. L. Toppen. Inorg. Chem. 12, 1404-1407 (1973).

129. K. Kustin, S.-T. Liu, C. Nicolini, D. L. Toppen. J. Am. Chem. Soc. 96, 7410-7415 (1974).

130. K. Kustin and D. L. Toppen. J. Am. Chem. Soc. 95, 3564-3568 (1973).

131. P. O. I. Virtanen, S. Kurkisuo, H. Nevala, S. Pohjola. Acta Chem. Scand. A40, 200-206 (1986).

132. A. Neves, W. Walz, K. Wieghardt, B. Nuber, J. Weiss. Inorg. Chem. 27, 2484-2489 (1988).

133. P. C. Wilkins, M. D. Johnson, A. A. Holder, D. C. Crans. Inorg. Chem. Under review.

134. M. Ding, P. M. Gannett, Y. Rojanasakul, K. Liu, X. Shi. J. Inorg. Biochem. 55, 101-112 (1994). 
135. E. E. Kriss, K. B. Yatsimirskii, G. T. Kurbatova. Khimiya Tekhnol. Vanadievykh Soedin. 364-368 (1974).

136. A. Sreedhara, N. Susa, C. P. Rao. Inorg. Chim. Acta 263, 189-194 (1997).

137. Y. Sun, B. R. James, S. J. Rettig, C. Orvig. Inorg. Chem. 35, 1667-1673 (1996).

138. N. A. Daugherty. J. Phys. Chem. 68, 612-616 (1964).

139. K. Wuethrich and R. E. Connick. Inorg. Chem. 7, 1377-1388 (1968).

140. M. D. Johnson and R. K. Murmann. Inorg. Chem. 22, 1068-1072 (1983).

141. O. Yokoyama, H. Tomiyasu, G. Gordon. Inorg. Chem. 21, 1136-1141 (1982).

142. K. Saito and Y. Sasaki. Adv. Inorg. Bioinorg. Mech. 1, 179-216 (1982).

143. T. M. Che and K. Kustin. Inorg. Chem. 19, 2275-2280 (1980).

144. E. Kiss, I. Fabian, T. Kiss. Inorg. Chim. Acta 340, 114-118 (2002).

145. B. R. Nechay, L. B. Nanninga, P. S. E. Nechay, R. L. Post, J. J. Grantham, I. G. Macara, L. F. Kubena, T. D. Phillips, F. H. Nielsen. Fed. Proc. 45, 123-132 (1986).

146. R. L. Van Etten, P. P. Waymack, D. M. Rehkop. J. Am. Chem. Soc. 96, 6782-6785 (1974).

147. L. C. Cantley, Jr., L. Josephson, R. Warner, M. Yanagisawa, C. Lechene, G. Guidotti. J. Biol. Chem. 252, 7421-7423 (1977).

148. A. F. Nour-Eldeen, M. M. Craig, M. J. Gresser. J. Biol. Chem. 260, 6836-6842 (1985).

149. D. G. Drueckhammer, J. R. Durrwachter, R. L. Pederson, D. C. Crans, L. Daniels, C.-H. Wong. J. Org. Chem. 54, 70-77 (1989).

150. D. C. Crans, C. M. Simone, J. S. Blanchard. J. Am. Chem. Soc. 114, 4926-4928 (1992).

151. D. C. Crans, R. W. Marshman, R. Nielsen, I. Felty. J. Org. Chem. 58, 2244-2252 (1993).

152. S. Kadota, I. G. Fantus, G. Deragon, H. J. Guyda, B. I. Posner. J. Biol. Chem. 262, 8252-8256 (1987).

153. S. Kadota, I. G. Fantus, G. Deragon, H. J. Guyda, B. Hersh, B. I. Posner. Biochem. Biophys. Res. Comm. 147, 259-266 (1987).

154. A. P. Bevan, P. G. Drake, J.-F. Yale, A. Shaver, B. I. Posner. Mol. Cell. Biochem. 153, 49-58 (1995).

155. B. I. Posner, C. R. Yang, A. Shaver. Vanadium Compounds, Chemistry, Biochemistry, and Therapeutic Applications, ACS Symposium Series Vol. 711, pp. 316-329, American Chemical Society, Washington, DC (1998).

156. K. H. Thompson, J. H. McNeill, C. Orvig. Chem. Rev. 2561-2571 (1999).

157. D. Rehder. Inorg. Chem. Commun. 6, 604-617 (2003).

158. G. R. Willsky, A. B. Goldfine, P. J. Kostyniak, J. H. McNeill, L. Q. Yang, H. R. Khan, D. C. Crans. J. Inorg. Biochem. 85, 33-42 (2001).

159. M. W. Makinen and M. J. Brady. J. Biol. Chem. 277, 12215-12220 (2002).

160. D. Mustafi, A. Bekesi, B. G. Vertessy, M. W. Makinen. Proc. Natl. Acad. Sci. USA 100, 5670-5675 (2003).

161. D. C. Crans, E. M. Willging, S. K. Butler. J. Am. Chem. Soc. 112, 427-432 (1990).

162. M. J. Gresser, A. S. Tracey, P. J. Stankiewicz. Adv. Prot. Phosphatases 4, 35-57 (1987).

163. D. C. Crans, C. M. Simone, A. K. Saha, R. H. Glew. Biochem. Biophys. Res. Commun. 165, 246-250 (1989).

164. G. Huyer, S. Liu, J. Kelly, J. Moffat, P. Payette, B. Kennedy, G. Tsaprailis, M. J. Gresser, C. Ramachandran. J. Biol. Chem. 272, 843-851 (1997).

165. C. Cuncic, N. Detich, D. Ethier, A. S. Tracey, M. J. Gresser, C. Ramachandran. J. Biol. Inorg. Chem. 4, 354-359 (1999).

166. D. C. Crans, C. M. Simone, R. C. Holz, L. Que, Jr. Biochemistry 31, 11731-11739 (1992).

167. J.-S. Lim, M. A. S. Aquino, A. G. Sykes. Inorg. Chem. 35, 614-618 (1996).

168. D. R. Davies and W. G. J. Hol. FEBS Lett. 577, 315-321 (2004).

169. M. Zhang, M. Zhou, R. L. Van Etten, C. V. Stauffacher. Biochemistry 36, 15-23 (1997).

170. Y. Shechter and S. J. D. Karlish. Nature 284, 556-558 (1980). 
171. G. R. Dubyak and A. Kleinzeller. J. Biol. Chem. 255, 5306-5312 (1980).

172. C. E. Heyliger, A. G. Tahiliani, J. H. McNeill. Science 227, 1474-1477 (1985).

173. J. Meyerovitch, Z. Farfel, J. Sack, Y. Shechter. J. Biol. Chem. 262, 6658-6662 (1987).

174. A. B. Goldfine, D. C. Simonson, F. Folli, M.-E. Patti, C. R. Kahn. Mol. Cell. Biochem. 153, 217-231 (1995).

175. A. B. Goldfine, D. C. Simonson, F. Folli, M.-E. Patti, C. R. Kahn. J. Clin. Endo. Metab. 80, 3311-3320 (1995).

176. G. R. Willsky, A. B. Goldfine, P. J. Kostyniak. Vanadium Compounds, Chemistry, Biochemistry, and Therapeutic Applications, ACS Symposium Series Vol. 711, pp. 278-296, American Chemical Society, Washington, DC (1998).

177. H. Sakurai, K. Tsuchiya, M. Nukatsuka, M. Sofue, J. Kawada. J. Endocrinol. 126, 451-459 (1990).

178. H. Watanabe, M. Nakai, K. Komazawa, H. Sakurai. J. Med. Chem. 37, 876-877 (1994).

179. H. Sakurai, K. Fujii, H. Watanabe, H. Tamura. Biochem. Biophys. Res. Commun. 214, 1095-1101 (1995).

180. H. Sakurai, K. Fujii, S. Fujimoto, Y. Fujisawa, K. Takechi, H. Yasui. Vanadium Compounds, Chemistry, Biochemistry, and Therapeutic Applications, ACS Symposium Series Vol. 711, pp. 344-352, American Chemical Society, Washington, DC (1998).

181. A. Katoh, M. Yamaguchi, R. Saito, Y. Adachi, H. Sakurai. Chem. Lett. 33, 1274-1275 (2004).

182. J. H. McNeil, V. G. Yuen, H. R. Hoveyda, O. C. J. Med. Chem. 35, 1489-1491 (1992).

183. V. G. Yuen, C. Orvig, J. H. McNeill. Can. J. Pharmacol. 71, 263-269 (1993).

184. B. A. Reul, S. S. Amin, J.-P. Buchet, L. N. Ongemba, D. C. Crans, S. M. Brichard. Br. J. Pharm. 126, 467-477 (1999).

185. D. S. Greco and D. C. Crans. J. Inorg. Biochem. (2005). Under revision.

186. H. Yasui, K. Takechi, H. Sakurai. J. Inorg. Biochem. 78, 185-196 (2000).

187. E. Kiss, E. Garribba, G. Micera, T. Kiss, H. Sakurai. J. Inorg. Biochem. 78, 97-108 (2000).

188. G. R. Willsky, L.-H. Chi, D. C. Crans. In Proceedings of International Symposium on Bio-trace Elements 2002, S. Enomoto and Y. Seko (Eds.), pp. 119-124, RIKEN, Wako, Saitama, Japan (2003). 